\title{
Phylogeny of Tacca (Taccaceae) and traits in reproductive structures, with description of a new Bornean species
}

\author{
WONG SIN YENG ${ }^{1,2, \boldsymbol{v}}$, CHUA KEK SHEN ${ }^{1}$ \\ ${ }^{1}$ Faculty of Resource Science and Technology, Universiti Malaysia Sarawak. 94300 Kota Samarahan, Sarawak, Malaysia. Tel: +60-82583028, \\ vemail: sywong@unimas.my. \\ ${ }^{2}$ Research Associate, Harvard University Herbaria. 22 Divinity Avenue, Cambridge, MA 02138, United States of America
}

Manuscript received: 1 September 2019. Revision accepted: 3 October 2019.

\begin{abstract}
Wong SY, Chua KS. 2019. Phylogeny of Tacca (Taccaceae) and traits in reproductive structures, with description of a new Bornean species. Biodiversitas 20: 3096-3118. A phylogenetic study of 16 of the c. 20 Tacca species is presented using nuclear ITS and plastid matK gene regions. Tacca leontopetaloides and T. maculata are a sister clade to the rest of the Tacca species. Tacca palmata and T. palmatifida are strongly supported together in a clade with this clade sister to T. bibracteata and T. plantaginea. All endemic Bornean taxa except $T$. bibracteata formed a derived clade together with non-Bornean T. cristata and T. sumatrana. The Bornean taxa are separated into three clades with $T$. borneensis sister to the other two clades. Twelve morphological characteristics are coded and mapped onto the Maximum Parsimony tree to elucidate potential evolutionary patterns. Results indicated shifts from a geophytic (irregularly-) seasonally dormant to an evergreen mesophytic habit, a decompound to a simple leaf blade, a long to a short peduncle, green to darkcolored inflorescences, numerous to few inner bracts, bracteoles, and flowers, and a low to an increased number of ovules. Within the Bornean taxa, there is a reversal from showy bracts and elaborate inflorescences to less showy bracts and simplified inflorescences. Tacca cristata Jack is resurrected from within T. integrifolia Ker Gawl. sensu Drenth. A new species, Tacca havilandii S.Y.Wong \& K.S.Chua from Borneo is described.
\end{abstract}

Keywords: Borneo, ITS, matK, new species

\section{INTRODUCTION}

Tacca J.R.Forst \& G.Forst (Taccaceae, Stevens 2001 onwards) comprises about 20 species (Govaerts et al. 2007; Lim and Raguso 2017) of (irregularly-) seasonally dormant tuberous-stemmed geophytes or rhizomatous evergreen mesophytes of still uncertain relationship within Dioscoreales (Drenth 1976). Tacca is principally speciose in humid tropical and subtropical Asia, with about four species (Tacca lanceolata Benth. ex. Seem., T. parkeri Seem., T. Sprucei Benth., and T. ulei H.Limpr.) in the American tropics, and two species (T. ankaranensis Bard.Vauc. and T. artocarpifolia Seem.) on Madagascar. Tacca leontopetaloides (L.) Kuntze (treated sensu Drenth 1972) occurs in coastal beach-forest around much of the South China Sea, with extensions into northern Australia and the tropical western Pacific as far east as Fiji, and westwards across India, Madagascar, and throughout equatorial Africa. The remaining Asian species have more restricted distributions from northeast India and southern sub-tropical China, southeast to Peninsular Malaysia and the Indonesian archipelago, and the Philippines east to New Guinea and the Solomon Islands (Drenth 1976)

Tacca inflorescences are unique and readily distinguishable consisting of conspicuous sterile elements, including two pairs of showy involucral bracts and profuse filiform bracteoles subtending the umbelliform inflorescence (Lim and Raguso 2017). Flowers are colored white to yellow-gray to greenish-purple or black. There are two infructescence types among Tacca spp. according to the manner in which the fruits are held: either the scape remains erect or bends over by means of swelling on the inner side of the scape (i.e., nearest to the plant) with the fruits maturing on the ground (Saw 1993).

Previous phylogenies recognized between two to seven families in Dioscoreales (Caddick et al. 2002a; Wilkin et al. 2005; Merckx et al. 2006; Merckx et al. 2009; Merckx and Smets 2014; Hertweck et al. 2015; Trias-Blasi et al. 2015). Taccaceae is recognized as a separate family in Dioscoreales (Stevens 2001 onwards; Mabberley 2017). For interspecific relationship in Tacca, Caddick et al. (2002a) included six Tacca taxa with T. integrifolia Ker Gawl. as sister to the other species, which is morphologically implausible. Wilkin et al. (2005) provided a topology more in keeping with morphological characteristics, and which by and large supported by the studies that followed (Merckx et al. 2009; Zhang et al. 2011; Merckx and Smets 2014). Zhang et al. (2011) included nine Tacca taxa (T. ampliplacenta L.Zhang \& Q.J.Ling, T. chantrieri André, T. subflabellata P.P.Ling \& C.T.Ting, T. parkeri, T. plantaginea (Hance) Drenth, T. cristata Jack (misidentified as $T$. integrifolia), $T$. leontopetaloides, T. palmata Blume, and T. palmatifida Baker) with the last four species from Malesia. Based on evolutionary trends inferred from molecular phylogenetic results, bracts and bracteoles in Tacca have become larger and more conspicuous, including a proliferation of bracteoles, from an ancestor with small and inconspicuous such features (Zhang et al. 2011). 
To date, there are no samples included from Borneo in phylogenetic studies. There are six Tacca occurring on Borneo and these are highly diversified with heteromorphic and homeomorphic involucral bracts, periodically dormant and evergreen species, and a wide range of the number of associated filiform bracteoles making inclusion of these taxa into a phylogeny a prerequisite to better enable understanding the evolutionary context of these morphological characteristics. This study set out to include species with larger involucral bracts (T. borneensis Ridl.) or smaller involucral bracts (T. bibracteata Drenth and $T$. reducta P.C.Boyce \& S.Julia) to test the evolutionary patterns. Thus, the objectives of this study were: (1) to further explore the phylogenetic relationship among Tacca spp. with the inclusion of Bornean taxa, and (2) to investigate the evolutionary trends of morphological characteristics among the species.

\section{MATERIALS AND METHODS}

\section{Taxon sampling}

Sixteen species were included in this study: $T$. ampliplacenta, T. bibracteata, T. borneensis, T. chantrieri, T. cristata, T. havilandii S.Y.Wong \& K.S.Chua, T. integrifolia, T. leontopetaloides, T. maculata Zipp. Ex Span., T. palmata, T. palmatifida, T. plantaginea, $T$. reducta, T. subflabellata, T. sumatrana H.Limpr., and Tacca sp. nov. 1, as well as one unidentified taxon (Figure 1; Table S1). Eighty-eight new sequences from mat $\mathrm{K}$ and ITS regions were generated from 44 accessions of 12 Tacca spp. (accession numbers from MK144475MK153235) together with 21 sequences (nine taxa) were downloaded from NCBI (Table S1). Seven taxa were not included in previous studies: T. bibracteata, T. borneensis, T. havilandii, T. maculata, T. reducta, T. sumatrana, and a confirmed novelty (Tacca sp. nov. 1). Sequences of Trichopus sempervirens (H.Perrier) Caddick \& Wilkin (Trichopodaceae) were downloaded as the outgroup (Hertweck et al. 2015; Zhang et al. 2011).

\section{DNA extraction, amplification, and sequencing}

DNA was extracted from leaf samples using DNeasy Plant MiniKit (Qiagen, Hilden, Germany) according to the protocol. For DNA amplification, the PCR mix contained $2.0 \mu \mathrm{l}$ of DNA, $0.4 \mu \mathrm{l}$ of primer $(10 \mathrm{mM}), 4.0 \mu \mathrm{l}$ of $10 \mathrm{X}$ buffer, $0.2 \mu \mathrm{l}$ of dNTP $(10 \mathrm{mM}), 1.6 \mu \mathrm{l}$ of $\mathrm{MgCI}_{2}(25 \mathrm{mM})$, $0.2 \mu \mathrm{l}$ of Taq polymerase (PROMEGA), and doubledistilled water was added to $20 \mu \mathrm{l}$. For amplifying ITS region, $1 \mu \mathrm{DMSO}$ was added. The matK gene region was amplified using two pairs of primers: 19F with 1326R primers of Molvray et al. (2000) and Cuenoud et al. (2002), and $390 \mathrm{~F}$ with $2 \mathrm{R}$ primers of Cuenoud et al. (2002) and Johnson and Soltis (1994). For ITS, primers 18F (Kass and Wink 1997, modified by Beyra-Matos and Lavin 1999) and 26R (Kass and Wink 1997) were used. The PCR process began with DNA denaturation for $2 \mathrm{mins}$ at $95^{\circ} \mathrm{C}$, followed by 30 cycles of $1 \mathrm{~min}$ at $95^{\circ} \mathrm{C}$ for denaturation, $1 \mathrm{~min}$ at $50^{\circ} \mathrm{C}$ or $52^{\circ} \mathrm{C}$ for annealing, 2 mins at $72^{\circ} \mathrm{C}$ for extension, lastly followed by a final extension of $10 \mathrm{~min}$ at $72^{\circ} \mathrm{C}$. Negative controls were included in each PCR process to test for presence of contamination. Final PCR products were purified using GeneJET purification kit (Thermo Scientific, Massachusetts, USA) prior to sequencing. Then, purified PCR reactions were sent to Apical Scientific Sdn. Bhd. at Selangor, Malaysia for sequencing.

\section{Sequence alignment and phylogenetic analyses}

Newly generated sequences for both regions were manually trimmed and assembled for each accession. These sequences were combined with previously generated sequences for each region. The data matrices were aligned using MUSCLE (Edgar 2004) as implemented in Geneious Pro v5.6.4 (Biomatters Ltd, Auckland, New Zealand; www.geneious.com; Kearse et al. 2012) followed by minor manual adjustment following the similarity criterion (Simmons 2004). Indels were treated as missing data.

Phylogenetic analyses were conducted using Maximum Parsimony (MP), Maximum Likelihood (ML) and Bayesian inference (BI) to estimate tree topologies based on three datasets (ITS, matK and combined sequences). MP was implemented in PAUP ver. $4.0 \mathrm{a} 163$ (Swofford 2002). In MP analysis, characters were treated as unordered and equally weighted. Heuristic searches were computed with 1000 jackknife replicates and branch swapping by tree bisection reconnection (TBR).

jModelTest ver. 2.1.9 (Darriba et al. 2012) was used to choose the best nucleotide substitution model and parameter settings for each aligned datasets in ML and BI analyses by using the Akaike information criterion (AIC). For computing ML analysis, the aligned sequences were partitioned into the TIM3+G model and TPM1uf(K81uf)+G model for ITS and matK region respectively. For BI analysis, the data were analyzed with the GTR + G model. For ML analysis, the sequence files were uploaded to online RAxML Blackbox ver. 0.6.0 (Kozlov et al. 2018). BI phylogenetic trees were inferred in MrBayes ver. 3.2.6 (Huelsenbeck and Ronquist 2001) for all datasets. The phylogenetic tree presented was based on ML analysis because the resulting topologies for each analyses were consistent.

For the ML analyses, optimal gene trees were searched by optimizing topology, branch lengths, and model. 100 bootstrapping replicates of random sequences were estimated. Bayesian inference was conducted based on four independent Markov Chain Monte Carlo (MCMC) chains. The MCMC chains were run simultaneously and sampled every 500 generations for a total of 1 million generations. First $10 \%$ of the 2001 sampled trees were discarded as burn-in.

FigTree ver. 1.4.3 (Rambaut 2016) was used to view and save trees produced in all analyses. Bootstrap (BS) or posterior probability (PP) values of less than $50 \%$ or 0.50 were not presented on the resulting phylogenetic trees. Branches with BS or PP values of $85-100 \%$ or $0.85-1.00$ are regarded as strongly supported. 

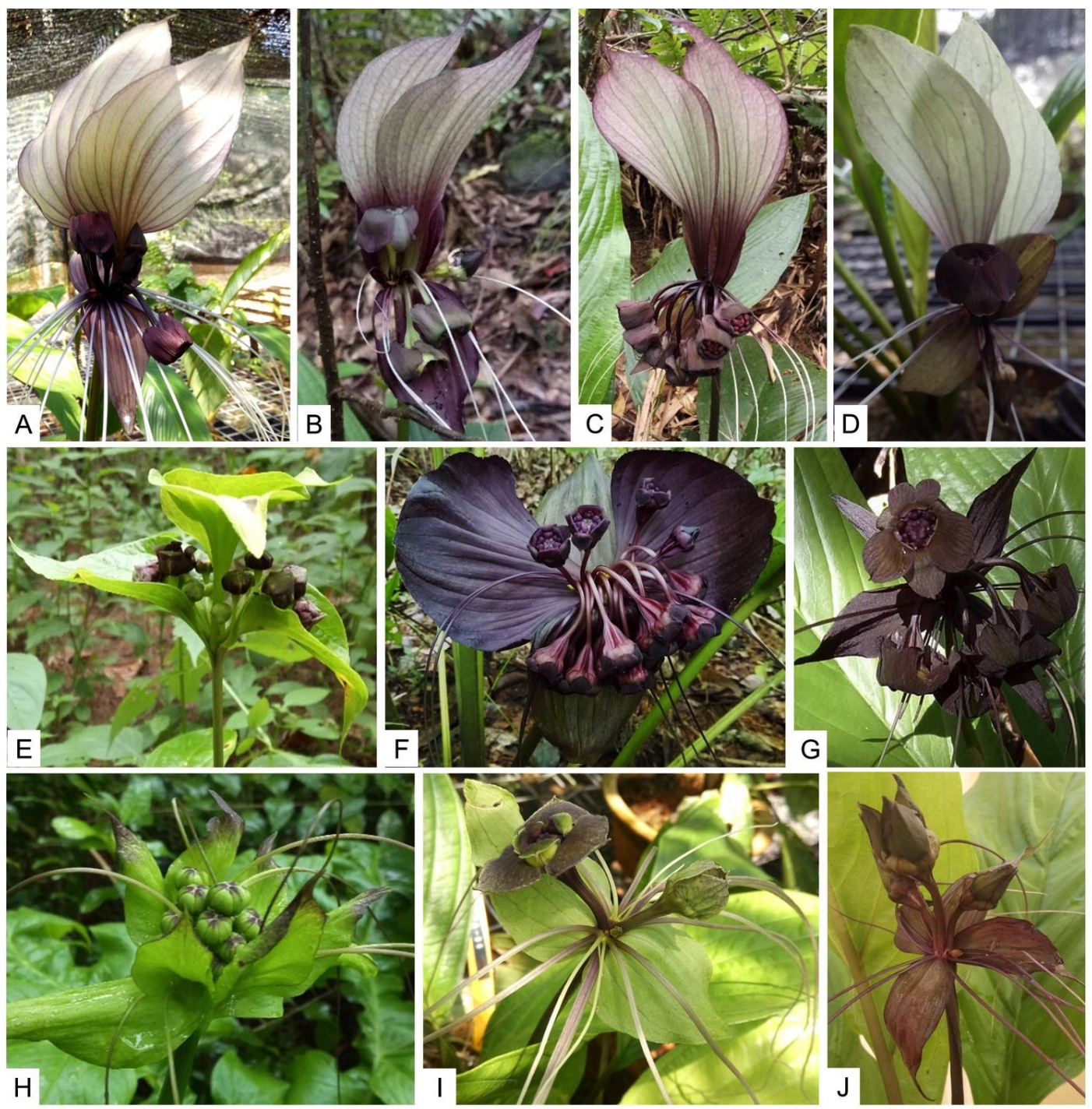

Figure 1. Inflorescence of Tacca species. A. T. integrifolia, B. T. havilandii, C. T. cristata, D. Tacca sp. nov. 1 TA46, E. T. palmata, F. T. borneensis, G. T. reducta, H. T. leontopetaloides, I. T. bibracteata, J. T. sumatrana. All photographs taken by Chua KS

\section{Morphological mapping}

As a starting point, we used all the morphologies (excluding involucral bract size) included in Zhang et al. (2011): bract color, bracteole length, and bracteole number. Second, we included morphologies based on descriptions from published reports (Drenth 1972; Phengklai 1980; Ling and Ting 1982; Boyce and Julia 2006; Hassan and Uddin 2007; Zhang et al. 2005; Zhang and Li 2008; Zhang et al. 2011) that were potentially informative for the taxon sampling in this study. Additional morphological characteristics, in particular, those found to vary within Tacca, were then added to the data set based on our own observations. Twelve morphological characters were identified and scored. Matrices were comprised of categorical data; four characteristics are binary and eight multistate (Table S2). Missing information is coded as "?". Included are habitat, one vegetative character (leaf blade outline, Figure 2), and ten reproductive characters (length of peduncle, outline of outer and inner involucral bracts, number of inner bracts, color of bracts, number of bracteoles, length of bracteoles, number of flowers, perianth persistent or not until fruiting, and number of ovules). The morphological data matrix was mainly based on the examination of herbarium specimens (on the website of JSTOR Global Plants, K, L, KEP, SAR), while field and cultivated specimen observations provided a secondary source (Table S3 and Table S4). Information on Trichopus was obtained from published work (Sivarajan et al. 1990; Caddick et al. 2002b; Wilkin et al. 2005). Variation in characters within taxa is scored as uncertainty (e.g., 0/1). Character matrices were analyzed in Mesquite ver. 3.51 (Maddison and Maddison 2018) using parsimony (unordered model) and likelihood under the Markov k-state one-parameter model (MK1), where all changes are equally probable. Matrices were mapped onto a MP tree based on the combined matK and ITS regions with one accession of each taxon (indicated in Table S1). 


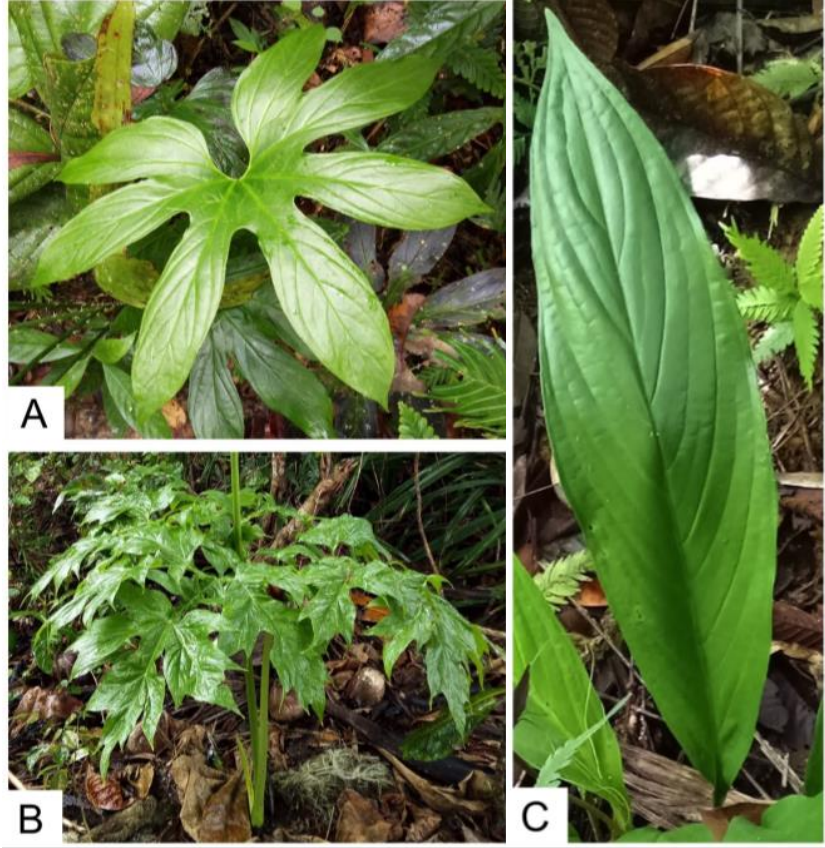

Figure 2. Leaves of Tacca species. A. T. palmata palmate., B. T. leontopetaloides decompound., C. T. reducta (entire). All photographs were taken by Chua KS

\section{Taxonomic study}

Fieldwork for pollination biology studies was undertaken in the state of Sarawak, Malaysian Borneo and in various localities in Peninsular Malaysia from February 2017 (Chua KS unpublished data). Examination of Tacca species sensu Drenth $(1972,1976)$, and re-examination of specimens deposited at the Sarawak Forestry Herbarium (SAR), Forest Research Institute Malaysia (KEP), and Singapore (SING), as well as specimen images on the website of JSTOR Global Plants, Kew (K), and Leiden (L) were carried out. All nomenclatural Types were examined. Vouchers (dried specimens and spirit material) resulting from this are deposited at SAR.

\section{RESULTS AND DISCUSSION}

\section{Phylogenetic reconstruction}

The final alignment for the combined sequences for the two regions (ITS and matK) comprised 2596 base pairs (bp) which included 402 (15.49\%) informative sites (Table $1)$. The ITS and matK regions consisted of $830 \mathrm{bp}$ and 1766 bp respectively, which contributed $10.32 \%$ and 5.28 $\%$ of the informative sites, respectively.
A well-supported phylogenetic tree was generated from analyses of the two selected loci (Figure 3) which is similar to the tree topology based on ITS alone (Figure S1) and congruent with the phylogenetic analysis of the combined five gene regions (ITS, $a t p \mathrm{~A}, r b c \mathrm{~L}, t r n \mathrm{~L}-\mathrm{F}$, and $t r n \mathrm{H}-p s b \mathrm{~A}$; Zhang et al. 2011). Tacca leontopetaloides and T. maculata formed the sister clade to all other Tacca species (MP BS = $100 \%, \mathrm{ML} \mathrm{BS}=100 \%, \mathrm{BI} \mathrm{PP}=1.00)$. Tacca maculata is next to T. leontopetaloides from Sarawak, Malaysia (MP $\mathrm{BS}=66 \%, \mathrm{ML} \mathrm{BS}=72 \%, \mathrm{BI} \mathrm{PP}=1.00)$. Tacca leontopetaloides is a geographically widespread species, occurring primarily in coastal beach-forest throughout much of the South China Sea, extending into northern Australia and the tropical western Pacific as far as Fiji, and westwards across India, Madagascar, and throughout tropical Africa (Drenth 1972). Tacca maculata occurs in N Australia, Fiji and, Samoa (Williams 2012) in dry coastal forest but not beach forest (Smith 1979). Tacca maculata is currently treated as a synonym of $T$. leontopetaloides (Drenth 1972). However, Drenth worked almost exclusively from herbarium specimens, recognizing far too few. While superficially very similar, T. maculata is generally much smaller than $T$. leontopetaloides, and differs by having the bracts equal to or shorter than flower (whereas in $T$. leontopetaloides the bracts exceed than flowers, narrower leaflets with parallel edges (Haudricourt 1942; Drenth 1972; Smith 1979). Their habitats are also different in which $T$. leontopetaloides grows on valley floor and beach whereas $T$. maculata occurs on rocky slope vegetation (Drenth 1972; Cowie and Stuckey 2008). All the species of the sister clade ( $T$. leontopetaloides and $T$. maculata) to all the rest Tacca species are geophytes with seasonally deciduous leaves, and one or two (at most four) complexly divided leaf blades, and berry-like fruits.

Tacca plantaginea, T. bibracteata, T. palmatifida, and T. palmata form a clade but with very low support values. This group comprises species with entire ( $T$. plantaginea, T. bibracteata) or divided (palmate) leaf blades and a semigeophytic habit. Tacca bibracteata, endemic to Borneo, has a robust semi-hypogeal creeping rhizome, heteromorphic involucral bracts, and is the only species within the clade with filiform inner bracts (Boyce and Julia 2006). Tacca plantaginea, occurs from South China to South Thailand, has homeomorphic involucral bracts with linear triangular inner bracts (Hassan and Uddin 2007). Tacca plantaginea has septicidal dehiscent fruits otherwise unknown species in the genus (Hassan and Uddin 2007). According to Zhang et al. (2011), T. parkeri from the New World is closely related to $T$. plantaginea. Thus, $T$. parkeri and more accessions of $T$. plantaginea and T. bibracteata from other localities need to be included to clarify the relationships of

Table 1. Statistics of tree support according to the separate and combined analyses of ITS and matK region

\begin{tabular}{lccccccc}
\hline Gene region & No. of taxa & No. of characters & No. of variable sites & No. of informative sites & Tree length & CI & RI \\
\hline ITS & 54 & 830 & 268 & 253 & 121 & 674 & 0.77 \\
mat $\mathrm{K}$ & 53 & 1766 & 402 & 377 & 446 & 0.92 & 0.95 \\
Combined & 53 & 2596 & & 377 & 1040 & 0.82 & 0.92 \\
\hline
\end{tabular}

Note: CI: consistency index, RI: retention index 


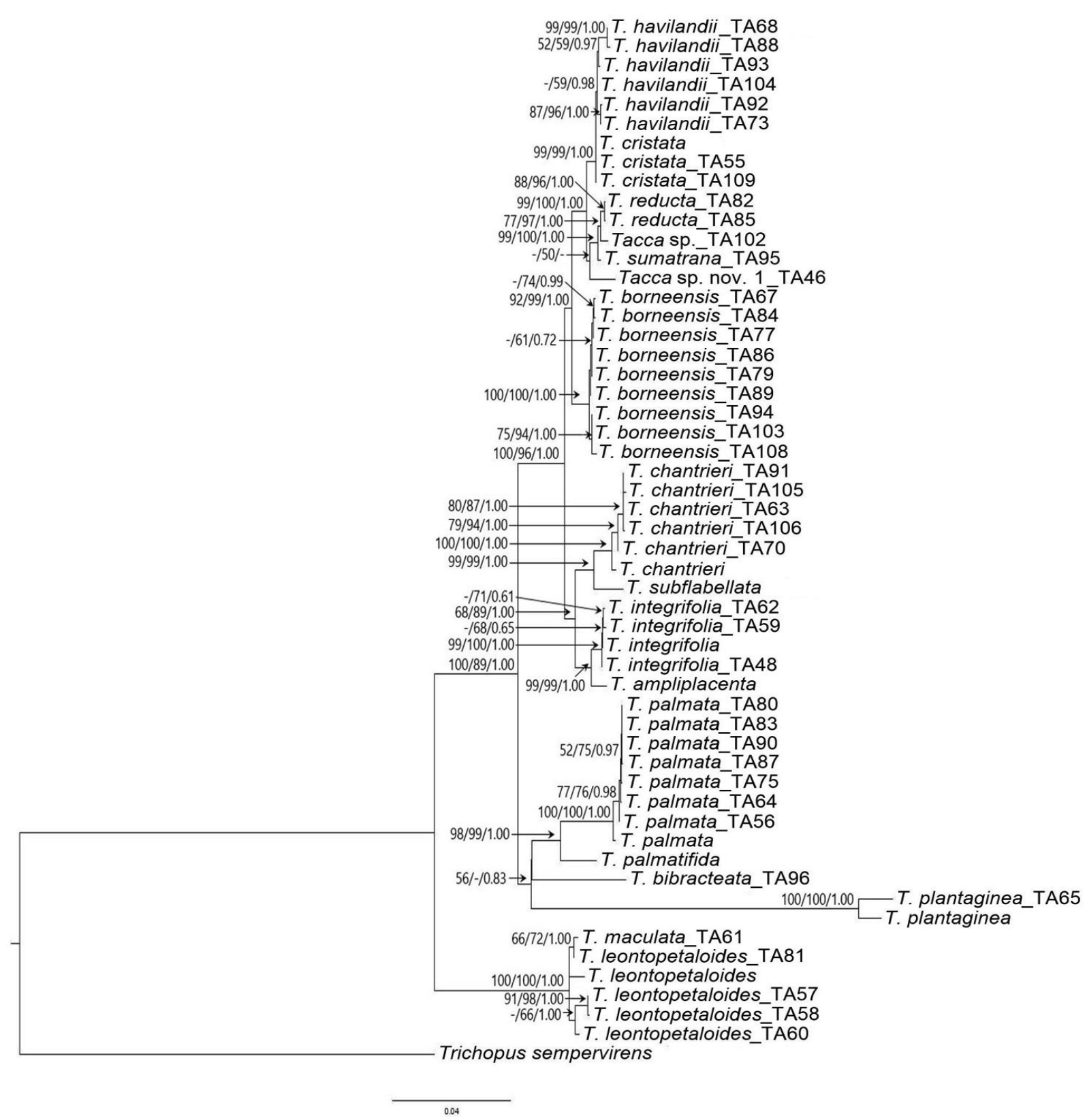

Figure 3. Phylogenetic relationships of Tacca species according to Maximum Likelihood analysis of combined data sets with supporting values above the branch (numbers from left to right indicate Maximum Parsimony bootstrap, Maximum Likelihood bootstrap, and Bayesian Inference posterior probability; “-” indicates bootstrap value less than 50)

these taxa. Tacca palmata, regardless of their origin, forms a subclade together with $T$. palmatifida with strong supporting values $(\mathrm{MP} \mathrm{BS}=98 \%, \mathrm{ML} \mathrm{BS}=99 \%, \mathrm{BI} \mathrm{PP}=$ 1.00) in all analyses. Both of these species are characterised with a palmate leaf blade and an absence of bracteoles (Drenth 1972).

All the rest of the clades in Tacca are comprised of species that are evergreen, rhizomatous, and have entire leaf blades. Tacca ampliplacenta, T. chantrieri, $T$. integrifolia and T. subflabellata formed a clade (MP BS = $68 \%, \mathrm{ML} \mathrm{BS}=89 \%$, BI PP = 1.00) in which $T$. ampliplacenta and $T$. integrifolia are together, with $T$. chantrieri and T. subflabellata in another subclade, both with high supporting values $(\mathrm{MP} \mathrm{BS}=99 \%, \mathrm{ML} \mathrm{BS}=$ $99 \%$, BI PP $=1.00)$. But from matK analysis, $T$. integrifolia formed a clade with $T$. subflabellata, while $T$. chantrieri came together with $T$. ampliplacenta (Figure S2). Both $T$. ampliplacenta and $T$. subflabellata were sampled from Yunnan province, southwestern China (Ling and Ting 1982; Zhang and Li 2008). Tacca ampliplacenta and T. subflabellata were recorded to be closely resembling T. chantrieri by having similar bracts but differs by having intumescent placenta (T. ampliplacenta) and inner bracts suborbicular-fan shaped (vs broadly ovate in T. chantrieri) (Ding and Larsen 2000; Zhang and Li 2008). Moreover, T. ampliplacenta was suggested to be the hybrid of 
outcrossing between $T$. chantrieri and $T$. integrifolia (Zhang and Li 2008).

All Bornean species (except T. bibracteata, T. palmata, and T. leontopetaloides) were grouped together with nonBornean $T$. cristata and T. sumatrana $(\mathrm{MP}$ BS $=92 \%, \mathrm{ML}$ $\mathrm{BS}=99 \%$, BI PP $=1.00)$. Accessions of $T$. borneensis form a strongly supported clade (MP BS $=100 \%$, ML BS $=$ $100 \%$, BI PP $=1.00)$. The clade was separated from the other two subclades. Tacca borneensis has large, ovate bracts and broad ovate leaf blades with an oblique base, distinctive from all other Bornean species (Boyce and Julia 2006). Tacca sp. nov. 1 (TA46) was found either as sister to $T$. reducta and $T$. sumatrana with very low support value (ML BS $=50 \%$ ) or formed a polytomy with $T$. cristata, $T$. reducta, T. havilandii, and T. sumatrana (MP and $\mathrm{BI}$ ). Tacca sp. nov. 1 (TA46) shared spathulate inner bracts with $T$. cristata and $T$. havilandii, but has linear triangular outer bracts similar to those of $T$. reducta and $T$. sumatrana (Figure 1), typically only one or two flowers per inflorescence, and highly distinctive erose-serrate petiole wings. Its taxonomic novelty has been confirmed by Saw LG and Ong PT (pers. comm.); it is often found associated with limestone in Peninsular Malaysia.

The remainder of the taxa formed two clades: the first group comprises species with linear triangular bracts $(T$. reducta, T. sumatrana, and Tacca $\mathrm{sp}$. TA102; MP BS = $99 \%, \mathrm{ML} \mathrm{BS}=100 \%, \mathrm{BI} \mathrm{PP}=1.00)$ and the second, species with spathulate bracts (T. cristata and T. havilandii; MP BS $=99 \%$, ML BS $=99 \%$, BI PP = 1.00). Species in the first group have homeomorphic and linear triangular bracts (Boyce and Julia 2006). Tacca reducta occurs on limestones in West Sarawak and West Kalimantan (Boyce and Julia 2006) while geological habitat of T. sumatrana was not recorded. According to Drenth (1972), $T$. sumatrana is a synonym of $T$. integrifolia. However, we observed that $T$. sumatrana differs from $T$. integrifolia by not possessing inflorescence with spathulate inner bracts (Figure 1.A and Figure 1.J). Thus, T. sumatrana should be resurrected as an accepted species. Tacca sumatrana and $T$. reducta develop inflorescence with high structural resemblance in terms of involucral bracts and bracteoles, but they are differentiable by that the leaf blade of $T$. sumatrana is ovate-elliptic (Limpricht 1928) and T. reducta is narrowly elliptic (Boyce and Julia 2006). Tacca sp. (TA102) from Java, Indonesia is placed in the same clade and observed to possess similar inflorescence characteristics to $T$. reducta and $T$. sumatrana (linear triangular involucral bracts and reduced number of flowers).

The second clade, includes a novel species, $T$. havilandii from Borneo, and T. cristata. Tacca cristata was originally collected from Singapore, and recorded from Peninsular Malaysia, Borneo, Java, and Sumatra (Limpricht 1928; Haudricourt 1942). Drenth (1972) synonymized $T$. cristata with $T$. integrifolia owing to their somewhat similar inflorescences (heteromorphic bracts: spathulate inner bracts and ovate outer bracts) but Zhang et al. (2011) and our study reveal only a distant relationship between $T$. cristata with $T$. integrifolia. Plants hitherto identified as T. integrifolia (sensu Drenth 1972) occurring in Peninsular Malaysia, Singapore, and Borneo belong to two discrete species, T. cristata (Peninsular Malaysia and Singapore) and T. havilandii (Borneo) (see below) while true $T$. integrifolia is a species occurring from NE India through to SW China.

\section{Character mapping analyses}

The character with the greatest number of parsimonious steps (eight steps) was the number of ovules (Table S5). Three characters each had seven steps: length of bracteoles, inner bracts outline, and perianth persistent till fruiting. The $-\log \mathrm{L}$ values from likelihood reconstruction of these characters ranged from 23.571-16.479. Consistency index (CI) of habitat, leaf blade outline, color of bract and number of inner bracts was 1.0 which indicated these characters were best fit on the tree. This was followed by number of bracteoles and outer bract outlines with $\mathrm{CI}=$ 0.83 and 0.67 , respectively. Other characters also had a considerably high CI (0.40-0.60), except perianth persistent until fruiting $(\mathrm{CI}=0.29)$. For the retention index $(\mathrm{RI})$, the characters with high-recorded values were leaf blade outline $(\mathrm{RI}=1.0)$ and color of bracts $(\mathrm{RI}=0.8)$. Retention index of other characters ranged from 0.4-0.5, except for habitat, perianth persistent till fruiting and number of inner bracts $(\mathrm{RI}=0)$.

Habitat:-Tacca leontopetaloides is the only species recorded growing in coastal beach areas; all others occur in secondary lowland forest (Figure 4). Tacca leontopetaloides is a seasonally deciduous tuberous plant, with the starchy tuber replaced during each growth phase, in marked contrast to the rest of Tacca species in the study, which have either perennial tubers or rhizomes (Drenth 1972). Morphologies of T. leontopetaloides which imply adaptation to coastal areas are the annual life cycle with tuber also regenerating/spreading by runners, and the seeds covered with spongy testa that likely facilitate floating and thus water dispersal (Drenth 1972). Based on our observations, T. leontopetaloides possesses a monophyllous module with one inflorescence per module whereas the perennially tuberous $T$. palmata and $T$. palmatifida lack runners and have oligophyllous modules, although also with solitary inflorescence. The rest of Tacca species have polyphyllous modules with several inflorescences per module.

Leaf-blade outline:-A decompound (Boyce et al. 2013) leaf blade - i.e., the blade trisect, with pinnately divided segments, and the primary divisions pinnatisect, bipinnatisect or dichotomously further divided, rarely undivided, and the highest order divisions (leaflets) entire, never fenestrate or lobed and only ever with one tip and bases decurrent, rarely petiolulate is plesiomorphic for the genus Tacca (Figure 4). An entire leaf margin is a derived character within Tacca. This is congruent with the evidence from the fossils of $T$. umerii A.D.Pan, B.F.Jacobs \& E.D.Currano which was dated as Early Miocene (21.7 Mya) and which had leaf blades with palmate lobes (Pan et al. 2014). Under the current taxonomy $T$. parkeri (including $T$. ulei and $T$. sprucei) can have be entire or pinnatipartite blades, although the evidence is that this is an artefact of imperfect taxonomy. As currently defined $T$. 
parkeri, Zhang et al. (2011) placed $T$. parkeri next to $T$. plantaginea together in a clade.

Length of peduncle:- Species in the basal have the longest peduncle, with the length of peduncle proportionately decreasing in other species (Figure 4). The length of peduncle is suggested to be related to the fruit/seed dispersal strategies (Saw 1993). In $T$. leontopetaloides, the peduncle remains erect even once the fruits have ripened (to yellow). A similar strategy was observed in T. palmata in which, fruit ripen to red. Saw 1993) suggested that bright color fruits may be attractive to birds which are probably the dispersal agents. However, no bird has yet to be seen feeding on the fruits of these species (Chua KS unpublished data). All other species in this study have a peduncle that swells on one side at the base after flowering, causing the peduncle to bend over and as a consequence, the fruits mature on the ground. The fruits of these species are probably dispersed by small mammals (Saw 1993) although again observations are wanting.

Outer bracts outline:-A pair of ovate outer bracts is one of the character states which is possessed by most of the species (Figure 4). The surface area of ovate outer bracts is generally larger than the linear triangular shaped. As mentioned in Zhang et al. (2011), Tacca probably evolved to develop larger bracts. Yet, the outer bracts were reduced to linear triangular in the derived clade as observed in $T$. reducta and $T$. sumatrana. The pair of outer bracts cover all other floral parts, especially the flower buds, throughout the early development of inflorescence. Hence, its function is probably to protect the developing flower buds from exterior threats such as florivore and/or atmospheric conditions. This explains the necessity of $T$. borneensis, $T$. cristata, and T. havilandii to develop larger size of outer bracts to cover the large inner bracts and abundance of flowers before the inflorescence blooms. During anthesis, both of these bracts are located at unnoticeable position (behind and below other floral structures) on the inflorescence. Thus, the likelihood and efficiency of the outer bracts pair being attractive to pollinators seem insignificant.

Number of inner bracts:-Among the studied species, only $T$. leontopetaloides commonly have inflorescences with more than two inner bracts (Figure 4). This species develops up to 10 inner bracts, with a range between six or eight inner bracts. The rest of the Tacca spp. normally only have two inner bracts, although inflorescences of $T$. havilandii were occasionally observed exceptionally with three inner bracts.

Inner bracts outline:- The shape and size of the inner bracts is a distinctive taxonomic character among most Tacca spp. (Boyce and Julia 2006), with spathulate or ovate inner bracts larger than filiform and linear triangular. Contrasting with outer bracts, the inner bracts were generally larger in the derived clade (Figure 4). This result is similar to the previous study by Zhang et al. (2011). However, the inclusion of $T$. bibracteata, T. reducta and $T$. sumatrana with rather linear inner bracts reveals a further reduction in the size of inner bracts in two separate clades, $T$. bibracteata and $T$. plantaginea, and $T$. reducta and $T$. sumatrana. With the reduction of the size of inner bracts in the derived clade ( $T$. reducta and $T$. sumatrana), makes the current hypotheses of Zhang et al. (2011) doubtfully acceptable. If the inner bracts are supposed to play a role in increasing reproductive success, why do species in the derived clade have smaller bracts? The reduction in area of bracts might be a mechanism in a trade-off between other floral traits, such as developing more bracteoles (Figure 4).

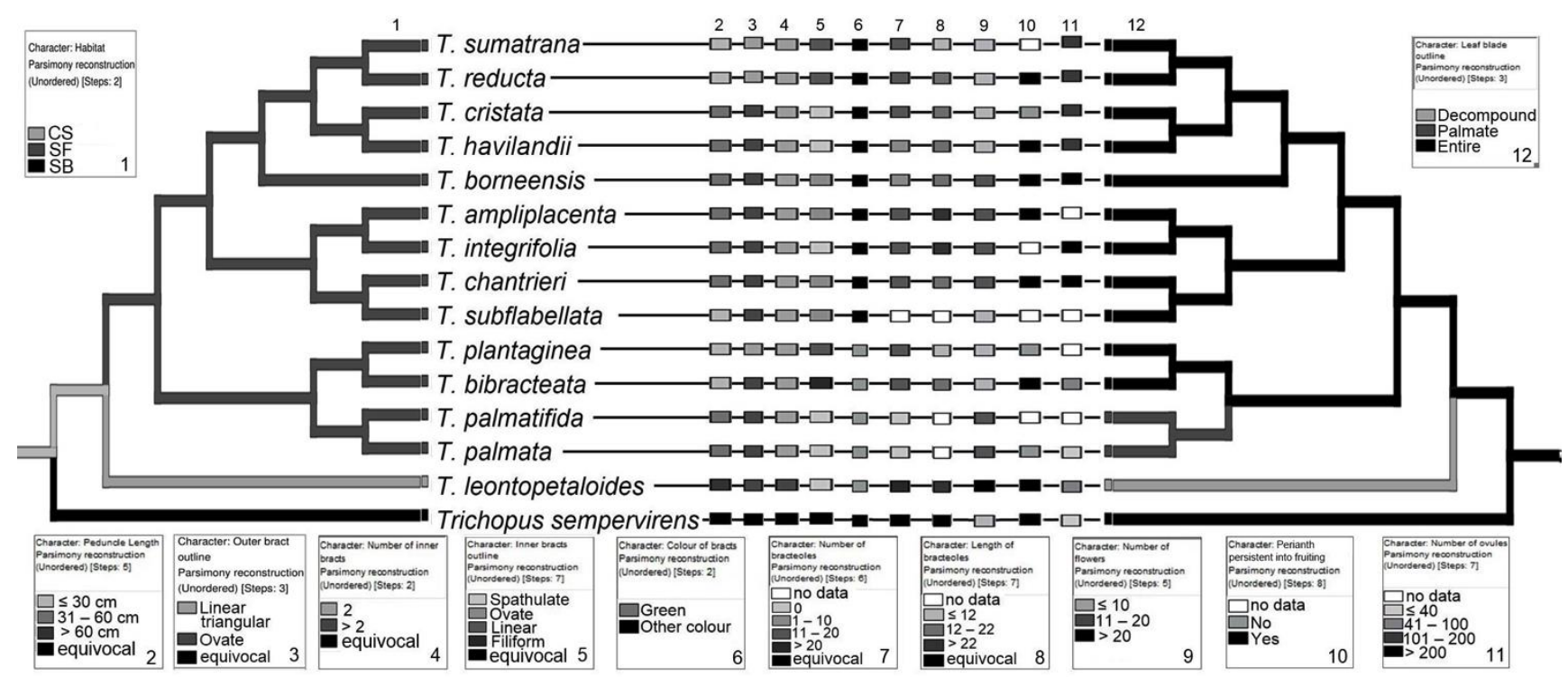

Figure 4. Morphological characteristics mapped onto the Maximum Parsimony tree based on the combined regions of ITS and matK. (Character 1: Habitat, Character 2: Peduncle length, Character 3: Outer bract outline, Character 4: Number of inner bracts, Character 5: Inner bracts outline, Character 6: Color of bracts, Character 7: Number of bracteoles, Character 8: Length of bracteoles, Character 9: Number of flowers, Character 10: Perianth persistent till fruiting, Character 11: Number of ovules, Character 12: Leaf blade outline) 
Color of bracts:- Green bracts were assumed to be the plesiomorphic character state and dark purple or white derived (Figure 4). The green inner bracts of $T$. leontopetaloides and $T$. palmata are observed to be persistent until fruit maturation. As these two species only produce one to three leaves, retaining involucral bracts of the inflorescence may aid photosynthesis for generating resources for fruit development (Zhang et al. 2005, 2011).

Number of bracteoles:-Tacca leontopetaloides has an inflorescence with more than 20 bracteoles. Bracteoles are lost in $T$. palmata and $T$. palmatifida. Zhang et al. (2005, 2007) speculated that the function of these filiform bracteoles is probably insignificant within the pollination success although their role as 'flickering bodies' (Vogel 2001) has yet to be properly investigated.

Length of bracteoles:-Similar to number of bracteoles, a decreasing pattern was noted in the length of bracteoles among Tacca spp., although $T$. ampliplacenta and T. integrifolia have bracteoles as long as those found in $T$. leontopetaloides. The significance of bracteoles towards fruit set is uncertain (Zhang et al. 2005). In terms of resource allocation, high investment of resources is required to maintain showy floral traits (Charlesworth and Charlesworth 1987). Thus, the reduction of allocated resources as observed in the decrease in number and length of bracteoles may indicate the decrease in significance of bracteoles for survival.

Number of flowers:- The number of flowers developing is most highest in $T$. leontopetaloides and shows reduction across the phylogenetic tree (Figure 4). Floral reduction is probably an approach for decreasing geitonogamy. Furthermore, the decrease in flower number also limits the number of anthetic flowers to one or two flowers per inflorescence per day and opportunities for inbreeding are minimized. A reduction in bracteoles and flowers might be a trade-off for other floral traits that are more likely to improve reproductive success. Resource for reproductive function was probably allocated to color or size of inner bracts or ovule number.

Perianth persistent until fruiting:-Most Tacca spp. have the perianth or at least part of the perianth persisting into fruiting. However, T. cristata, T. plantaginea, and $T$. palmata shed the perianth when the fruits began to develop. Reflexing of the perianth indicates the start of anthesis, with closing of perianth observed at the end of anthesis in a few species observed ( $T$. palmata and $T$. leontopetaloides). Other Bornean species (T. bibracteata, T. borneensis, T. reducta and $T$. havilandii) and $T$. cristata have the perianth remaining open after anthesis (Chua KS unpublished data).

Number of ovules:-For the number of ovules, the reconstruction of ancestral traits in the basal clade ( $T$. leontopetaloides) indicated that all species in the derived clade have more ovules. Species next to basal clade $(T$. bibracteata and $T$. palmata) have number of ovules either equal to/less than $T$. leontopetaloides. The development of ovule overproduction is a "bet-hedging" strategy on sporadic deposition of large amounts of pollen (Seger and Brockmann 1987; Burd 1995).

This parental optimism adaptation was observed in the evolution direction of Tacca spp. which have higher ovules number per flower, yet empirical observation proved that the pollinator visitation was stochastic (Mock and Forbes 1995; Lim and Raguso 2017). Selection on floral traits such as larger inner bracts among Tacca spp. may indirectly increase the production of ovule quantity, or vice versa (Figure 4). Ovule number role in plant reproduction is crucial in determining the maximum seed set capacity, and the potential size of the next generation population (Strelin and Aizen 2018).

\section{Taxonomic implications}

The most recent complete revision of Tacca is that of Drenth (1972) who, working almost exclusively from herbarium specimens, accepted just 10 Tacca species while creating a considerable synonymy for three of these species (T. chantrieri, T. integrifolia, and T. leontopetaloides). Drenth (1972) (justifiably) synonymized Schizocapsa Hance with Tacca and did not recognize three sections proposed by Limpricht (1928): Ataccia (Presl) Pax, Eutacca Pax, and Palmotacca Limpr. These three sections were distinguished based on the characters of the leaf and the presence or absence of the filiform bracts. As interpreted by Limpricht (1928), section Ataccia comprises entire-leaved species mostly with filiform bracts, Limpricht included $T$. parkeri which is entirely left but lacks filiform bracts; section Palmotacca of the simply palmatifid and palmatisect species all without filiform bracts. Limpricht included T. ulei and T. sprucei, species which Drenth (1972) synonymized with $T$. parkeri. Limpricht's Section Tacca (as 'Eutacca') consisted of all species allied to $T$. leontopetaloides and which Drenth included entirely within the synonymy of $T$. leontopetaloides.

Based on the phylogeny presented here and that of Zhang et al. (2011), section Tacca is well supported. This section is delimitated by its geophytic habit with annuallyreplaced tuberous subterranean stems, seasonally deciduous leaves with decompound leaf blades, a long erect peduncle, largely green inflorescences, more than two inner bracts, many filiform floral bracteoles, an abundance of flowers, and a low number of ovules per fruit. Plants occur often in coastal beach-forest throughout much of the South China Sea, extending into northern Australia and the tropical western Pacific as far as Fiji, and westwards as an inland plant across India, Madagascar, and throughout equatorial Africa.

Section Palmotacca is either supported as sister to section Ataccia (excluding T. plantaginea and T. parkeri) or is closely related to $T$. plantaginea and T. bibracteata, as in this study. Thus, the affinity of this section to the remainder of Tacca species remains unresolved. Nevertheless, Palmotacca is strongly supported as a clade. Palmotacca is readily distinguished by its semi-geophytic habit with perennial tuberous stems, irregularly deciduous to facultatively evergreen leaves, palmate leaf blades, an absence of filiform floral bracts, erect persistent photosynthetic inner bracts, and a low number of ovules per fruit. Berries ripen red or black. According to Limpricht (1928), Palmotacca can be divided into two smaller groups, viz. T. palmata with a tuberous short rhizome from which the leaves and inflorescences emerge 
from an apical cavity and in which the flowers are placed between the involucral bracts, and a group consisting of $T$. palmatifida and $T$. celebica Koord. with horizontally growing rhizome with the leaves and inflorescences spaced and no distinct apical growth and in which the flowers are inserted on the base of the inner involucral bracts. These are exclusively Old World species, from Cambodia to New Guinea (Drenth 1972).

Section Ataccia sensu Limpricht includes all entireleaved species in the Old World together with T. parkeri (a New World species). This section is defined by its mesophytic habit with creeping rhizomes, evergreen leaves, entire leaf blades, showy inflorescences, the presence of filiform floral bracts, and a high number of ovules per fruit. Tacca parkeri shares with species in section Ataccia entire leaves, but is similar to species in section Palmotacca in that it does not possess filiform floral bracts. Drenth (1972) however, synonymized $T$. ulei and $T$. sprucei into $T$. parkeri but although similar in their inflorescence characteristics, the three species are readily and consistently separable by their leaf characteristics. The position of $T$. bibracteata remains debatable as while $T$. bibracteata shares heteromorphic bracts with $T$. integrifolia, T. cristata, and T. havilandii, all bracts are filiform and furthermore green (vs oblong to spathulate and purple or black), and a low number of ovules per fruit, in these morphologies $T$. bibracteata is remarkably similar to T. plantaginea, a continental Asian species. Fully mature fruit of T. bibracteata has yet to be observed but it would be interesting to see if the fruits dehisce in a similar way to those of $T$. plantaginea, which was once placed in a separate genus, Schizocapsa based on this particular trait.

\section{New and resurrected species}

One of the outcomes of this study has to demonstrate that T. integrifolia sensu Drenth (1972) is unmistakably heterogenous and moreover that plants so determined from Peninsular Malaysia and Singapore and plants from Borneo similarly determined neither referable to $T$. integrifolia nor conspecific. A published name is available for the Peninsular Malaysian and Singaporean taxon - Tacca cristata Jack, and this we resurrect below. However, there is no published name for the Bornean elements and these are here described as a taxonomically novel species: Tacca havilandii S.Y.Wong \& K.S.Chua.

\section{Tacca havilandii S.Y.Wong \& K.S.Chua, sp. nov.}

Diagnosis:- Superficially similar to $T$. cristata on the basis of inflorescences carried above the foliage and in possessing heteromorphic inflorescence bracts but differing by the inner inflorescence bracts rather narrowly oblanceolate and long-decurrent (vs broadly spathulate with an abruptly long-clawed base), by the free-portion of each stamen with a pronounced fissure on the external side (vs free portion of stamen globose), and medium green of ripened fruits (vs ripening dark purple). In all plants of $T$. havilandii observed the stamens and stigma are very pale purple (never deep purple to brownish dark purple as typical for T. cristata).

Type:-MALAYSIA. SARAWAK. Kuching Division: F.R. near Kuching, d.x.o.b. (Haviland's cipher translates as: 10 October 1891), G.D. Haviland 1109 (holotype SAR!). (Figure 5.A, Figure 6).
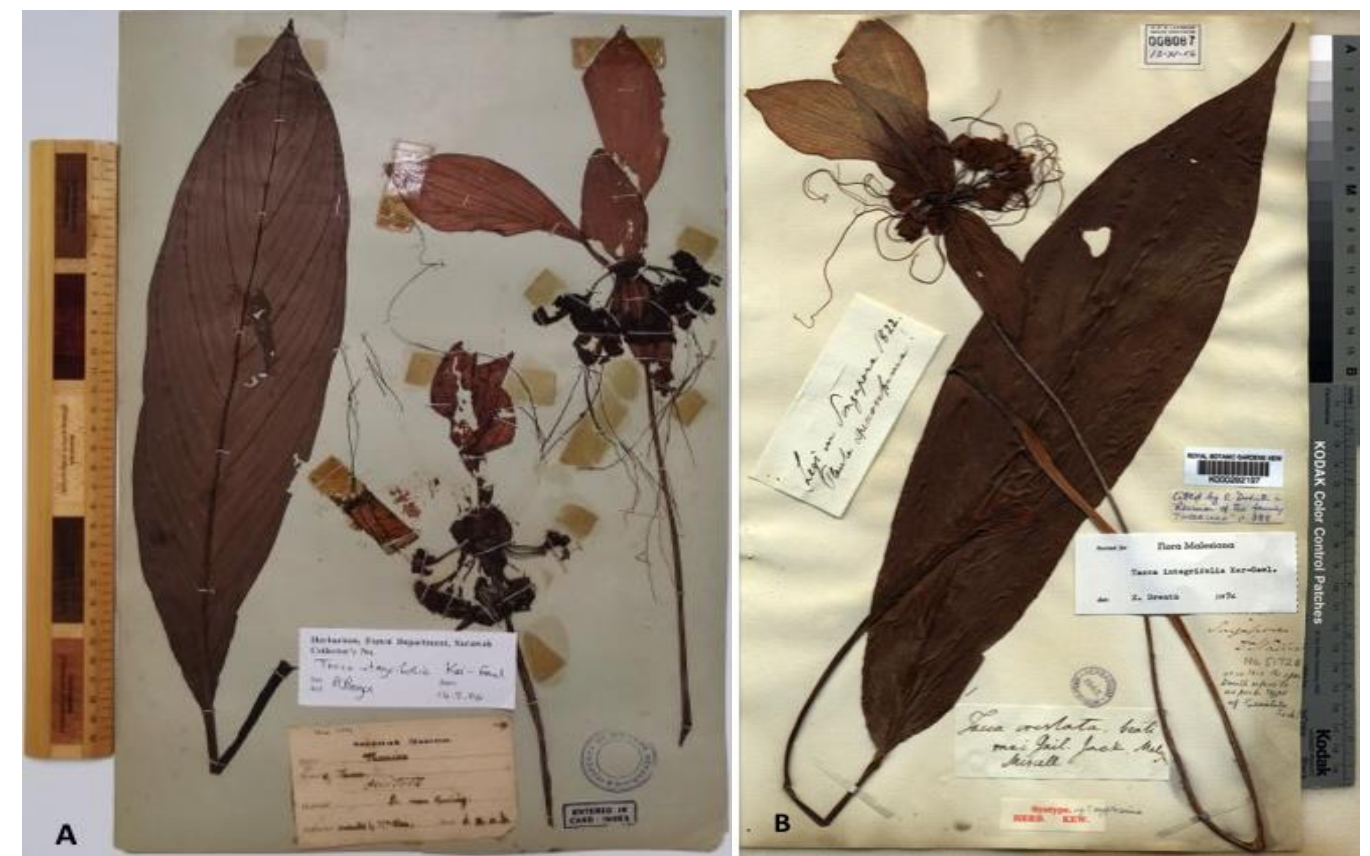

Figure 5. Holotype and lectotype. A. Holotype of Tacca havilandii S.Y.Wong \& K.S.Chua. B. Lectotype of Tacca cristata Jack 
Slender to moderately robust terrestrial mesophytic herb up to $73 \mathrm{~cm}$ tall. Stem erect to creeping-rhizomatous, hypogeal, if creeping then with the active apex ascending, up to $2.6 \mathrm{~cm}$ thick, clothed with persistent leaf bases and frequently rooting through these. Leaves 5-22 together, petioles ascending, 4.5-18 cm long, 9-12 mm diam., Dshaped in mid-cross-section, canaliculate, 2-keeled on the dorsal side, pale to mid-green sometimes stained purple at the base; petiolar sheath $c .1 / 5$ length of petiole, hyaline; lamina thinly to rather thickly coriaceous, ascending, lanceolate (sensu Lindley 1832), 40.6-67.4 cm × 8.8-12.5 $\mathrm{cm}$, base attenuate, decurrent, $c .5 \mathrm{~cm}$ along petiole, apex acute to acuminate, margins smooth, lamina pale to midgreen, glossy adaxially, paler and less glossy abaxially; midrib prominently raised abaxially, sunken adaxially, primary lateral veins $10-11$ per side, slightly sunken adaxially, inter primary lateral veins slightly less prominent than primaries, secondary veins forming a very obscure network with an obscure inter primary collecting vein running through the middle of each trans-inter primary tessellate area. Inflorescence up to three at different developmental stages per plant; peduncle erect, weakly 3 angled, 33-67 $\mathrm{cm}$ tall, pale green; involucral bracts heteromorphic: outer pair dorso-ventrally positioned, ovate, $6.8-9 \mathrm{~cm} \times 4-6.4 \mathrm{~cm}$, mid-purple; inner pair laterally positioned but ascending and ultimately sub-erect at anthesis, decurrent, oblanceolate, $8.5-12.8 \mathrm{~cm} \times 4.0-5.8$ $\mathrm{cm}$, basally mid-purple to pale whitish lavender purple toward tip; filiform bracteoles 6-13 per inflorescence, 7.6$36 \mathrm{~cm}$ long, mid-purple basally, fading to white at the tip. Flowers 3-12 per inflorescence; pedicel triangular in crosssection, $c .2 \mathrm{~cm}$ long, mid-purple fading to light green toward perianth, initially erect, later in anthesis reflexing, thence pendent; free-portion of each stamen with a pronounced fissure on the external side, gynoecium widely obpyramidal, $1.4 \mathrm{~cm}$ long $\times 1.3 \mathrm{~cm}$ wide at apex, 6-ribbed, greenish-purple, the ribs darker purple, perianth inserted annularly onto top of gynoecium. Outer perianth lobes oblong, rounded, $10-17 \mathrm{~mm} \times 5-8 \mathrm{~mm}$, reflexing at anthesis, greenish-purple; inner perianth lobes oblong, 15$18 \mathrm{~mm} \times 14-15 \mathrm{~mm}$, light purple. Infructescence declinate by twisting of the peduncle base, few to many-fruited, involucral bracts marcescent well prior to fruit maturation; fruit obpyramidal, bases rounded, ripening green 4.8-6.2 $\mathrm{cm} \times 2.9-3.3 \mathrm{~cm}$. Seeds weakly laterally compressedreniform, $5 \mathrm{~mm} \times 3 \mathrm{~mm}$, dark brown, 5-7-ribbed.

Additional specimens examined:-MALAYSIA. SARAWAK. Kuching Division: Ramungen, 5 Nov. 1954, W. M. A. Brooke 9436 (L.1464691!); Kuching, Dec. 1906, J. Hewitt 592 (SAR!); Bau, 4 Aug. 1916, W.H. Smith H. 1119-16 (K001140287!); Bau, Tanjung Durian, 14 Nov. 2003, P.C. Boyce TA-3 (SAR!); Bau, Serikin, P.C. Boyce TA-37 (SAR!); Bau, Kampung Segong, $1^{\circ} 31^{\prime} 12^{\prime \prime N}$, $110^{\circ} 08^{\prime} 18^{\prime \prime} \mathrm{E}, 53 \mathrm{~m}$ elev., Nov. 2017, collector unknown TA-92 (SAR!); Bau, Sungai Adis, $1^{\circ} 32^{\prime} 31^{\prime \prime N}, 110^{\circ} 09^{\prime} 04^{\prime \prime E}$, $60 \mathrm{~m}$ elev., 1 Jul. 2017, K.S. Chua TA-73 (SAR!); Matang, Sungai Rayu, 27 Mar. 1987, B.M.H. Lee S. 53351 (K!, K001140300!); Matang, Kubah National Park, $1^{\circ} 36^{\prime} 24^{\prime \prime N}$, $110^{\circ} 11^{\prime} 18^{\prime \prime E}, 306 \mathrm{~m}$ elev., Sept. 2017, K.S. Chua TA-88
(SAR!); Semenggoh Forest Research, Nov. 1958, Yacup S. 6546 (SAR!, K001140295 \& K001140296!, L.1464699 \& L.1464700!). Samarahan Division: Serian, Pichin, Kampung Kakang, Sungai Sisang, 14 Jan. 2005, P.C. Boyce \& Simon Kutuh ak Paru TA-19 (SAR!); Serian, Pichin, Ampan Pichin, 25 May 2005, P.C. Boyce \& Simon Kutuh ak Paru TA-36 (SAR!). Sarikei Division: Sungai Lepong, $01^{\circ} 57^{\prime} 12^{\prime \prime N}, 111^{\circ} 30^{\prime} 34^{\prime \prime E}, 8$ Dec. 2005, P.C. Boyce, Jeland ak Kisai, Jepom ak Tisai, Mael ak Late \& S.Y. Wong TA-33 (SAR!); Bayong, Ulu Sarikei, Lubok Lemba, $1^{\circ} 53^{\prime} 41^{\prime \prime N}, 111^{\circ} 30^{\prime} 11^{\prime \prime E}, 50 \mathrm{~m}$ elev., 3 Jun. 2017, S.Y. Wong \& P.C. Boyce TA-68 (SAR!). Kapit Division: Gat, Upper Rejang River, 1929, J. Clemens \& M.S. Clemens 22110 (K001140286!). Bintulu Division: Bukit Satiam, 02 59'26"N, 112 55'54"E, 11 Aug. 2004, P.C. Boyce \& Jeland ak Kisai TA-10 (SAR!); Bintulu, disturbed secondary forest of about 20 years of A. mangium cultivation, 14 Jul. 2006, P. Leong, B.C. Tan \& S.Y. Chin PL406 (KEP!); Miri Division: Baram, Sept. 1891, C. Hose 1357 (G.D. Haviland 949) (SAR!); Near Long Kapa, Ulu Tinjar, Mount Dulit, under $300 \mathrm{~m}$ elev., 1932, P.W. Richards 2630 (K001140289!); Long Berar, Trail to Long Berar, 15 Mar. 1981, I.S. Collenette 2340 (K001140299!); Marudi, Sungai Slat basin, Sungai Palutan, $2^{\circ} 50^{\prime} 32^{\prime \prime}$, 114059'12"E, S.P. Lim \& L. Banyeng S. 90414 (KEP!); Lawas, half day from Lawas, 12 Jul. 1955, W.M.A. Brooke 10230 (L.1464681!). SABAH. Sipitang, Ganui Forest Reserve, next to trail, c. $50 \mathrm{~m}$ from road, $4^{\circ} 59^{\prime} 44^{\prime \prime} \mathrm{N}$, 11541'00"E, 188 m elev., 17 Mar. 2011, J.T. Pereira, S. Suzana \& B. Baharam SAN153505 (KEP!); Keningau, Lanas, Shang Lian Logging areas, 18 Oct. 1986, Sumbing Jimpin SAN118418 (KEP!, K001140306!, L.1464692!); Tuaran, Tamparuli, Kampung Minangkob, Murug Turug waterfall, $6^{\circ} 07^{\prime} 35^{\prime \prime} \mathrm{N}, 116^{\circ} 21^{\prime} 19^{\prime \prime} \mathrm{E}, 257 \mathrm{~m}$ elev., 28 May 2018, S.Y. Wong \& P.C. Boyce TA-104 (SAN!); Mount Kinabalu, Dallas, $3000 \mathrm{ft}$ elev., 13 Nov. 1931, J. \& M.S. Clemens 27233 (K001140303!, L.1464698!); Tawau, Gunung Rara Forest Reserve, 3 Apr. 1997, Pereira, J.T. et al. JTP 440 (K001140361!); Sandakan, Sept.-Dec. 1920, M. Ramos 1356 (K001140281!); Sandakan, Oct. till Dec. 1921, A.D.E. Elmer 20277 (K001140291!); Sandakan, Sepilok, 552'09"N, 117'56'20"E, $81 \mathrm{~m}$ elev., 6 Feb. 2018, S.Y. Wong \& P.C. Boyce TA-93 (SAN!). INDONESIA. KALIMANTAN. Locality unknown P.W. Korthals s.n. (L.1464688!); locality unknown, 1857, W.H. de Vriese s. $n$. (L.1464686!); locality unknown, 1859, W.H. de Vriese \& J.E. Teijsmann s.n. (L.1464696 \& L.1464697!); Soeka Lanting, 1893, J.G. Hallier 71 (L.1464690!).

Eponymy:-Named for George Darby Haviland (1857-1901) a British surgeon and naturalist who served as Director of the Raffles Museum in Singapore as well as being a medical officer in Sarawak and Curator of the Sarawak Museum in Kuching between 1891 and 1893. In 1895 Haviland returned to England where he worked at the Kew Herbarium before going to South Africa where he disappeared in Natal while out bicycling. Although his abandoned bicycle was recovered his body was never found. Haviland was officially declared dead in 1907 (Stapf 1907). 


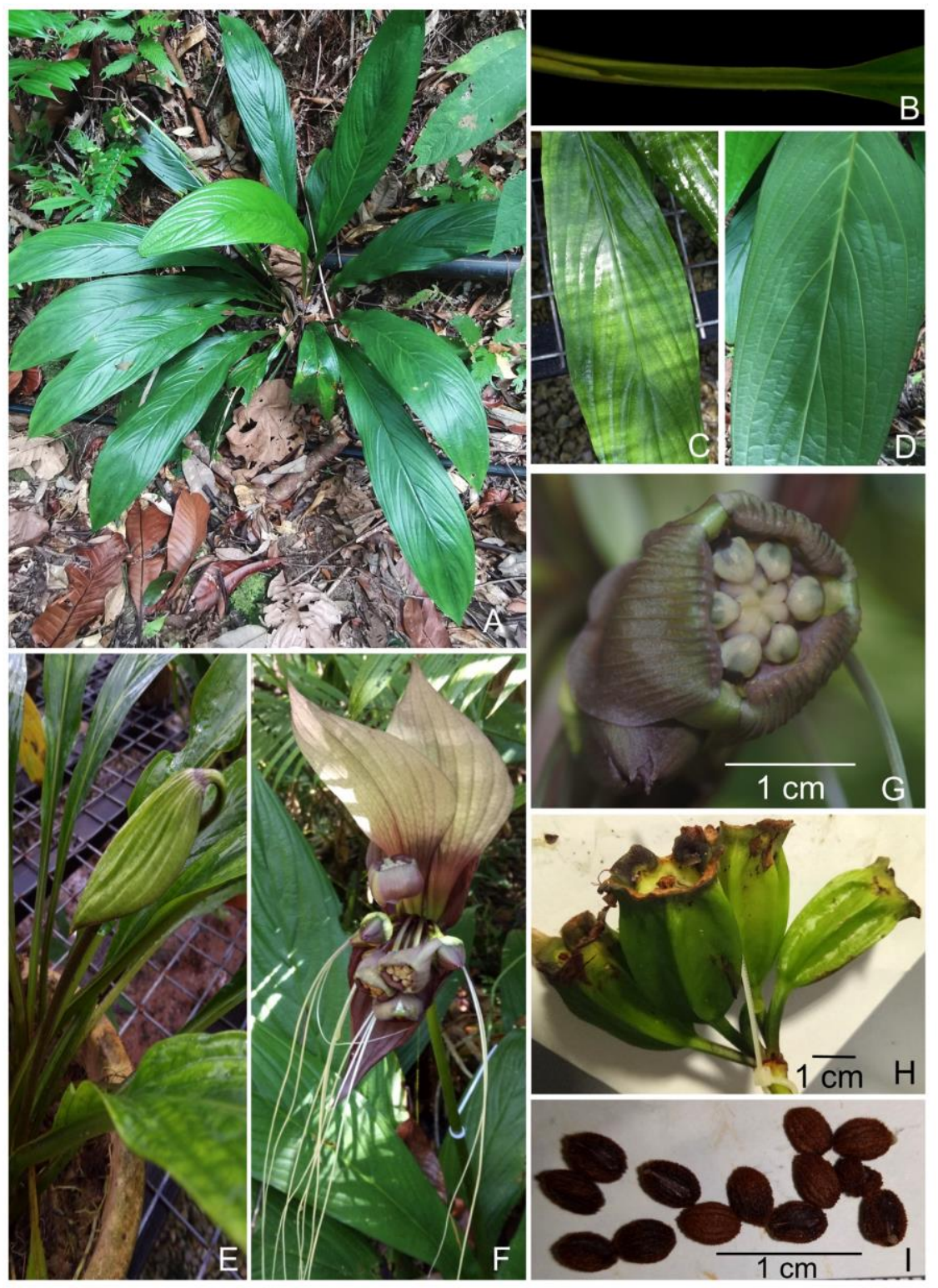

Figure 6. Tacca havilandii S.Y.Wong \& K.S.Chua. A. Whole plant. B. Petiole. C. Leaf lamina (adaxial). D. Leaf lamina (abaxial). E. Inflorescence bud. F. Inflorescence. G. Flower. H. Infructescence. I. Seeds. Photographs by Chua KS

Distribution and ecology:-Tacca havilandii is endemic to and widespread in northern Borneo, from Kuching Division (Sarawak, Malaysian Borneo) and Sambas District (Kalimantan Barat, Indonesian Borneo) in the west as far east as central Sabah and seemingly (material rather inadequate) as far south as northern reaches of the Kapuas drainages. The majority of populations occur in lowland to lower hill dipterocarp forest on leached clays in semi-shady positions.

Phenology:-Flowering and fruiting throughout the year with highest number of inflorescences recorded in March.

Note:-Recognition of $T$. havilandii for the Bornean elements hitherto referred to as $T$. integrifolia and the resurrection of $T$. cristata (see below), while enabling a much improved understanding of the delimitation and distribution of the Malesian elements of Drenth's patently heterogeneous taxon, still leaves on Borneo a wide range of morphological variation within $T$. havilandii (i.e., taxonomic variation within a species complex with fissured free stamens, as opposed to species- delimitation problems remaining within Peninsular species with entire free stamen segments) that likely reflect still imperfect circumscription. By way of examples, populations occurring in Kerangas in northeastern Sarawak in particular consistently produce far fewer flowers per inflorescence (often only two) and have with the erect lateral involucral bracts dull purple-brown and not shading from purple at the base to much paler with deeper purple veins distally. Likewise, plants in the central and northern coastal forests have consistently much fleshier involucral bracts. More work is required. 


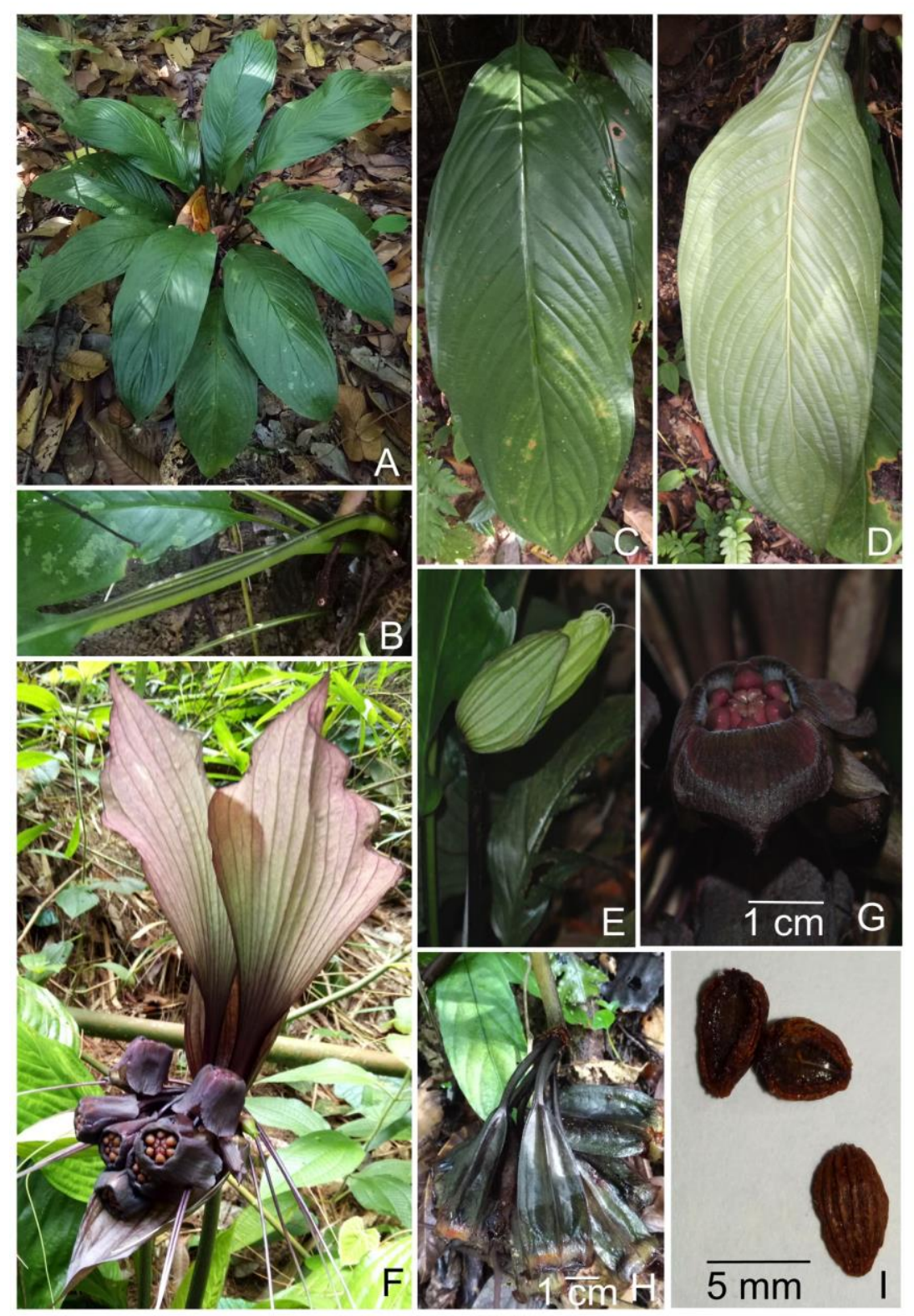

Figure 7. Tacca cristata Jack. A. Whole plant. B. Petiole. C. Leaf lamina (adaxial). D. Leaf lamina (abaxial). E. Inflorescence bud. F. Inflorescence. G. Flower. H. Infructescence. I. Seeds. Photographs by Chua KS

Tacca cristata Jack, Mal. Misc. I, 5 (1821) 23.

Type:-SINGAPORE. Wallich 5172B (K - Kew barcode K001120038- Lectotype designated here). (Figure 5B, Figure 7).

Slender to moderately robust terrestrial mesophytic herb to $1 \mathrm{~m}$ tall. Stem rhizomatous, hypogeal, creeping with the active apex ascending, up to $3 \mathrm{~cm}$ thick. Leaves 913 together, petiole ascending, c. $15 \mathrm{~cm}$ long, c. $6 \mathrm{~mm}$ diam, D-shaped in central cross-section, canaliculate, 2keeled on the dorsal side, dull purple or green with keeled area darker purple along petiole; petiolar sheath $c$. $1 / 5$ length of petiole, hyaline; lamina thickly coriaceous, ascending, oblong-elliptic to broadly lanceolate (sensu Lindley 1832), 40-65 $\mathrm{cm} \times$ (c. 9-) 15-17 cm, base rather broadly acute and thereafter shortly and narrowly alate, apex acuminate, margin smooth, lamina mid-green, glossy adaxially, paler and less glossy abaxially; midrib prominently raised abaxially, sunken adaxially, primary lateral veins 8-10 per side, slightly sunken adaxially, interprimary lateral veins slightly less prominent than primaries, secondary veins forming a very obscure network with an obscure interprimary collecting vein running through the middle of each trans-interprimary tessellate area. Inflorescences up to four at different developmental stages per plant; peduncle erect, weakly 3 angled, 46.2-65 $\mathrm{cm}$ tall, dark purple or brownish-green; involucral bracts heteromorphic: outer pair dorso-ventrally positioned, ovate, $9.8-14 \mathrm{~cm} \times c .6 \mathrm{~cm}$, mid-purple to dark purple; inner pair 
laterally positioned but ascending and ultimately sub-erect at anthesis, weakly and obscurely clawed (in most robust specimens) to decurrent (weaker specimens), spathulate, $c$. $15 \mathrm{~cm} \times$ c. $7 \mathrm{~cm}$, dark purple to mid-purple, purple margin and vein, pale purple or purplish green in the middle; filiform bracteoles 10-25 per inflorescence, up to $17 \mathrm{~cm}$ long, dark purple basally, fading to white at the tip. Flowers 4-19 per inflorescence; pedicel triangular in crosssection, 2.9-3.4 cm long, dark purple, initially erect, later in anthesis reflexing, thence pendent; free-portion of each stamen globose, gynoecium widely obpyramidal, 2.1-2.3 $\mathrm{cm}$ long $\times 1.5-1.6 \mathrm{~cm}$ wide at apex, 6-ribbed, purple, the ribs darker purple, perianth inserted annularly onto top of gynoecium. Outer perianth lobes ovate, rounded, c. $20 \mathrm{~mm}$ $\times$ c. $10 \mathrm{~mm}$, reflexing at anthesis, dark greenish-purple; inner perianth lobes broadly elliptic, c. $20 \mathrm{~mm} \times c .16 \mathrm{~mm}$, dark purple. Infructescence declinate by twisting of the peduncle base, few to many-fruited, involucral bracts marcescent well prior to fruit maturation; fruit obpyramidal, bases acute-tapering, ripening dark brownish purple, up to $5 \times 2.5 \mathrm{~cm}$. Seeds weakly laterally compressed-reniform, c. $5 \mathrm{~mm} \times$ c. $2 \mathrm{~mm}$, pale brown to dark brown, 10-11-ribbed.

Additional specimens examined:-MALAYSIA. PERAK. Larut, Aug. 1881, G. King's collector, 2174 (L.1464785!); Larut, Feb. 1882, G. King's collector, 2809 (K001140138!); Maxwell's Hill, 1885, L. Wray 123 (K001140139!); Changkat Mentin, Sept. 1918, Collector unknown 6526 (K001140140!). SELANGOR. Ramlan Panjang, 1914, H.N. Ridley, s.n. (K001140143!); Genting Bidai, H.N. Ridley, s.n. (K001140142!); Gombak F.R., old road to Genting Highlands, 13 Mar. 1996, P.C.Boyce 1074 (K001140150!); Gombak, Forest Research Institute Malaysia, 313'39"N, 101³6'56"E, 120 m elev., 17 Dec. 2016, S.Y. Wong \& P.C. Boyce TA-55 (SAR!); Kuala Lumpur, Bukit Nanas 3०09'09"N, 10142'07"E, 66 m elev., Jan. 2018, K.S. Chua TA-109 (SAR!); Ulu Gombak Forest Reserve, 8 Oct. 1925, FMS-10540 (KEP!); Ulu Langat, 7 Sept. 1917, C.B. Kloss s.n. (K001140147!); Bukit Lagong Forest Reserve, $c .3^{\circ} 15^{\prime} \mathrm{N}, 101^{\circ} 36^{\prime} \mathrm{E}, 100 \mathrm{~m}$, elev., 20 Feb. 1984, M.J.S. Sands 3512 (K001140149 \& K001140148!); Kepong, 2 Oct. 1929, C.F. Symington FMS-17543 (KEP!); Kajang, Sungai Lalang Forest Reserve, 11 Mar. 1930, C.F. Symington FMS-22799 (KEP!); Kuala Kubu Bharu, Bukit Kutu, 29 Dec. 1930, FMS-23248 (KEP!); Kajang, Hulu Langat, Gunung Nuang, $3^{\circ} 14^{\prime} \mathrm{N}, 101^{\circ} 54^{\prime} \mathrm{E}, 469 \mathrm{~m}$ elev., 7 Sept. 2016, L.G. Saw \& N. Mohamad Aidil FRI-80032 (KEP!); Ulu Semangko, 3 Sept. 1969, T.C. Whitmore FRI12566 (KEP!); Genting Sampah, Mar. 1917, H.N. Ridley, Robinson \& C.B. Kloss s.n. (K001140144!). NEGERI SEMBILAN. Bukit Tangga, 20 Dec. 1920, H.N. Ridley, s.n. (K001140152!); Kuala Pilah, 13 Mar. 1931, FMS-2146 (KEP!); Jelebu, Gunung Telapok Buruk, $2^{\circ} 50^{\prime} \mathrm{N}, 102^{\circ} 04^{\prime} \mathrm{E}$, 700 m elev., 8 Mar. 2010, S. Syahida Emiza, G. Staples \& H.L. Kueh FRI-66682 (KEP!); Jelebu, Kenaboi Forest Reserve, 6 Mar. 2014, $3^{\circ} 07^{\prime} \mathrm{N}, 102^{\circ} 03^{\prime} \mathrm{E}, \mathrm{K}$. Imin, A. Angan \& A. Julius FRI-81393 (KEP!). MELAKA. Herb Griffith 6023 (K001140153 \& K001140154!); Herb Griffith 6026 (K001140155!); Melaka, 1867, A.C. Herb Maingay 3171 (K001140156!); Melaka, Collector unknown, 2369
(K001140160!). JOHOR. Kluang, 18 Nov. 1922, R.E. Holttum 9422 (K001140151!); Mersing, Lenggor F.R., Bukit Tinggi, $2^{\circ} 17^{\prime} 16^{\prime \prime} \mathrm{N}, 103^{\circ} 40^{\prime} 12^{\prime \prime} \mathrm{E}, 3$ Apr. 2011, P.T. Ong, P. O'Byrne \& M.A. Nazri FRI 71439 (K001140132!). SINGAPORE. N. Wallich 5172 (K!).

Distribution and ecology:-Tacca cristata is only recorded from Peninsular Malaysia and Singapore where it is widespread as far north as Perak, occurring in lowland to lower hill moist to perhumid dipterocarp forest over granite.

Note:- Jack (1821) cites material collected from Pulau Penang and Singapore but without specifying any collection information. Drenth (1972) glossed over the typification of the name $T$. cristata with a rather vague statement that the type was probably Wallich s.n. and citing a photograph in the Bailey Hortorium and a $\mathrm{K}$ specimen but without giving further details. Kew herbarium has three Wallich sheets from Singapore and one from 'Malaysia' all under the same Wallich Catalogue number 5172. The 'Malaysia' specimen has two elements. The 5172A element labeled 'Pinang', and the 5172B element Singapore. The $5172 \mathrm{~A}$ is not pertinent to T. cristata (indeed it appears to be an undescribed species) while the 5172B element is in early fruit. Of the Singapore collections (all labeled on the sheet as 5172B) one is sterile (comprised of two large separate leaves), and two are fertile. One of these fertile sheets (Kew barcode K000292197) has a label to the effect that it was photographed for the Bailey Hortorium and is presumably the same specimen that Drenth mentioned. While fertile the specimen is at the lower end of the size and robustness of $T$. cristata. The other Singapore collection (Kew barcode K001120038) has inflorescences and fruits and is a far more typical representative of the species and is the specimen here selected as Lectotype.

Tacca cristata was described based on specimens from Singapore and Pulau Pinang (Jack 1821). However, based on field work by the second author and available herbarium specimens, T. cristata is absent from Penang and Pulau Pinang, occurring from Perak southwards to Singapore. Jack (1821), compared $T$. cristata with $T$. integrifolia notably differentiable by the two erect involucral bracts with flowers bending to one side, characteristics that are not reliable with comparison based on the original drawing of $T$. integrifolia (Ker Gawler 1812) in which the inflorescence was depicted post-anthesis. Tacca cristata is readily differentiated from $T$. integrifolia by the stigma with six regular radial grooves with the areas between the grooves of similar size (vs stigmatic grooves resulting in a triangular raised central section flanked by lower areas of tissues, by the inner inflorescence bracts with the claw only weakly raised and the bract arching but not conspicuously fornicate (vs inner inflorescence bracts with the claw conspicuously raised and the bracts strongly fornicate), and by the semi-glossy dark green leaf laminae with the primary lateral veins slightly impressed (vs leaf laminae highly polished brilliant green with primary lateral veins deeply impressed with the blade between the veins having a quilted appearance). 


\section{ACKNOWLEDGEMENTS}

Fieldwork in Sarawak was carried out under Research Permit No. NPW.907.4.4(JLD.14)-159 and Park Permit No. WL822017 from Sarawak Forestry Department. This paper forms part of the results obtained from a M.Sc. study of the second author. Funding by Ministry of Education Malaysia through Niche Research Grant Scheme No. NRGS/1089/2013-(03) is acknowledged.

\section{REFERENCES}

Beyra-Matos A, Lavin M. 1999. Monograph of Pictetia (LeguminosaePapilionoideae) and review of the Aeschynomeneae. Syst Bot Monogr 56: 1-93.

Boyce PC, Sookchaloem D, Hetterscheid WLA, Gusman G, Jacobsen N, Idei T, Van Du N. 2013. Araceae. Flora Thai 11: 1-221.

Boyce PC, Julia S. 2006. A review of entire-leaved Tacca (Dioscoreaceae) in Sarawak, Borneo. Gard Bull Singapore 58: 25-40.

Burd M. 1995. Ovule packaging in stochastic pollination and fertilization environments. Evolution 49: 100-109.

Caddick LR, Rudall PJ, Wilkin P, Hedderson TAJ, Chase MW. 2002a Phylogenetics of Dioscoreales based on combined analyses of morphological and molecular data. Bot J Linn Soc 138: 123-144.

Caddick LR, Wilkin P, Rudall PJ, Hedderson TAJ, Chase MW. 2002b. Yam reclassified: a recircumscription of Dioscoreaceae and Dioscoreales. Taxon 51: 103-114

Charlesworth D, Charlesworth, B. 1987. The effect of investment in attractive structures on allocation to male and female functions in plants. Evolution 41: 948-968.

Cowie ID, Stuckey BM. 2008. Threatened plants on the Bradshaw field training area. Dept. of Natural Resources, Environment and the Arts, Northern Territory, Australia.

Cuenoud P, Savolainen V, Chatrou LW, Powell M, Grayer RJ, Chase MW. 2002. Molecular phylogenetics of Caryophyllales based on nuclear $18 \mathrm{~S}$ rDNA and plastid $r b c \mathrm{~L}, a t p \mathrm{~B}$, and matK DNA sequences. Am J Bot 89: 132-144.

Darriba D, Taboada GL, Doallo R, Posada D. 2012. jModelTest 2: More models, new heuristics and parallel computing. Nat Methods 9: 772

Ding ZZ, Larsen K. 2000. Taccaceae. Flora China 24: 274-275.

Drenth E. 1972. A revision of the family Taccaceae. Blumea 20: 367-406.

Drenth E. 1976. Taccaceae. In: Van Steenis CGG (eds) Flora Malesiana ser. I, vol. 7: 806-819. Noordhoff International Publishing, Leiden.

Edgar RC. 2004. MUSCLE: Multiple sequence alignment with high accuracy and high throughput. Nucl Acids Res 32: 1792-1797.

Govaerts R, Wilkin P, Saunders RMK. 2007. World Checklist of Dioscoreales: Yams and their allies. Kew Royal Botanic Gardens, Kew.

Hassan MA, Uddin MZ. 2007. Tacca plantaginea (Hence) Drenth (Taccaceae) - A new angiospermic record for Bangladesh. Bangladesh J Plant Taxon 14: 71-73.

Haudricourt A. 1942. Les Tacca, plantes utiles. Revue de Botanique Appliquée et d'agriculture Colonial 22: 69-81. [In French].

Hertweck KL, Kinney MS, Stuart SA, Maurin O, Mathews S, Chase MW, Pires JC. 2015. Phylogenetics, divergence times and diversification from three genomic partitions in monocots. Bot J Linn Soc 178(3): 375-393.

Huelsenbeck JP, Ronquist F. 2001. MrBayes: Bayesian inference of phylogenetic trees. Bioinformatics 17: 754-755.

Jack W. 1821. Descriptions of Malayan plants, No. 2. Malayan Miscellanies 1: 1-49.

Johnson LA, Soltis DE. 1994. matK DNA sequences and phylogenetic reconstruction in Saxifragranceae s.str. Syst Bot 19: 143-156.

Kass E, Wink M. 1997. Phylogenetic relationships in the Papilionoideae (family Leguminosae) based on nucleotide sequences of cpDNA (rbcL) and ncDNA (ITS 1 and 2). Molec Phylogen Evol 8: 65-88.

Kearse M, Moir R, Wilson A, Stones-Havas S, Cheung M, Sturrock S, Buxton S, Cooper A, Markowitz S, Duran C, Thierer T, Ashton B Meintjes P, Drummond A. 2012. Geneious basic: An integrated and extendable desktop software platform for the organization and analysis of sequence data. Bioinformatics 28: 1647-1649.
Ker Gawler JB. 1812. Tacca integrifolia. Botanical Magazine 36: Plate 1488.

Kozlov AM, Darriba D, Flouri T, Morel B, Stamatakis A. 2018. RAxMLNG: A fast, scalable, and user-friendly tool for Maximum Likelihood phylogenetic inference. bioRxiv, DOI: 10.1101/447110.

Lim GS, Raguso RA. 2017. Floral visitation, pollen removal, and pollen transport of Tacca cristata Jack (Dioscoreaceae) by female Ceratopogonid midges (Diptera: Ceratopogonidae). Int J Plant Sci 178: $341-351$

Limpricht W. 1928. Taccaceae. In: Engler A (eds.). Das Pflanzenreich: 132. Wilhelm Engelmann, Leipzig. [In Latin]

Lindley J. 1832. An Introduction to Botany. Longman, Rees, Orme, Brown, Green, \& Longman, London.

Ling P-P, Ting C-T. 1982. Two new species of Taccaceae from China. Acta Phytotax Sin 20: 202-204.

Mabberley D. 2017. Mabberley's Plant-book: A Portable Dictionary of Plants, their Classification and Uses. Cambridge University Press, Cambridge.

Maddison WP, Maddison DR. 2018. Mesquite: A modular system for evolutionary analysis, version 3.2. https://www.mesquiteproject.org.

Merckx V, Smets EF. 2014. Thismia Americana, the 101 ${ }^{\text {st }}$ Anniversary of a botanical mystery. Int J Plant Sci 175: 165-175.

Merckx V, Schols P, Maas-van de Kamer H, Maas P, Huysmans S, Smets E. 2006. Phylogeny and evolution of Burmanniaceae (Dioscoreales) based on nuclear and mitochondrial data. Am J Bot 93: 1684-1698.

Merckx V, Bakker FT, Huysmans S, Smets E. 2009. Bias and conflict in phylogenetic inference of myco-heterotrophic plants: a case study in Thismiaceae. Cladistics 25:64-77.

Mock DW, Forbes LS. 1995. The evolution of parental optimism. TREE 10: $130-134$.

Molvray M, Kores PJ, Chase MW. 2000. Polyphyly of mycoheterotrophic orchids and functional influences on floral and molecular characters. In: Wilson KL, Morrison DA. (eds) Monocots: Systematics and evolution: 441-448. CSIRO Publishing, Victoria.

Pan AD, Jacobs BF, Currano ED. 2014. Dioscoreaceae fossils from the late Oligocene and early Miocene of Ethiopia. Bot J Linn Soc 175: 17-28.

Phengklai C. 1980. Taccaceae. Thai Forest Bull 13: 23-33.

Rambaut A. 2016. FigTree, version 1.4.3 http://tree.bio.ed.ac.uk.

Saw LG. 1993. Tacca: Flowering and fruiting behaviour. Nat Malaysiana 18: 3-6.

Seger J, Brockmann HJ. 1987. What is bet-hedging? - In: Harvey PH, Partridge L (eds) Oxford surveys in evolutionary biology, vol. 4: 182211. Oxford University Press, Oxford.

Simmons MP. 2004. Independence of alignment and tree search. Molec Phylogen Evol 31: 874-879.

Sivarajan VV, Pushpangadan P, Ratheesh Kumar PK. 1990. A revision of Trichopus (Tricopodaceae). Kew Bull 45: 353-360.

Smith AC. 1979. Flora vitiensis nova: A new flora of Fiji (Spermatophytes only). Pacific Tropical Botanical Garden, Kauai.

Stapf O. 1907. XXXIV. - Miscellaneous Notes - G.D. Haviland. Bulletin of Miscellaneous Information: 197-198. Royal Botanic Gardens, Kew.

Stevens PF. 2001 onwards. Angiosperm Phylogeny Website. http://www.mobot.org/MOBOT/research/APweb/.

Strelin MM, Aizen MA. 2018. The interplay between ovule number, pollination and resources as determinants of seed set in a modular plant. PeerJ 6: e5384, https://doi.org/10.7717/peerj.5384.

Swofford D. 2002. PAUP*: Phylogenetic analysis using parsimony (* and other methods). Sinauer Associates, Sunderland.

Trias-Blasi A, Baker WJ, Haigh AL, Simpson DA, Weber O, Wilkin P. 2015. A genus-level phylogenetic linear sequence of monocots. Taxon 64: 552-581.

Vogel S. 2001. Flickering bodies: floral attraction by movement [Flimmerkörper: Bewegung als Locksignal in Blüten]. - Beiträge zur Biologie der Pflanzen 72: 89-154.

Wilkin P, Schols P, Chase MW, Chayamarit K, Furness CA, Huysmans S, Rakotonasolo F, Smets E, Thapyai C. 2005. A plastid gene phylogeny of the yam genus, Dioscorea: Roots, fruits and Madagascar. Syst Bot 30: 736-749.

Williams CJ. 2012. Medicinal plants in Australia: Plants, potions, and poisons, Vol. 3. Rosenberg Publishing Pry Ltd., Australia.

Zhang L, Li QJ. 2008. Tacca ampliplacenta (Taccaceae), a new species from Yunnan, China. Ann Bot Fenn 45: 311-314. 
Zhang L, Barrett SCH, Gao JY, Chen J, Cole WW, Liu Y, Bai ZL, Li QJ. 2005. Predicting mating patterns from pollination syndromes: The case of "sapromyiophily" in Tacca chantrieri (Taccaceae). Am J Bot 92: $517-524$

Zhang L, Chen J, Li DZ, Li QJ. 2007. Reproductive biology, mating system, and population genetics of devil flower: An autonomous selfing plant with showy floral display. Floriculture and Ornamental Biotech 1: 115-124.

Zhang L, Li HT, Gao LM, Yang JB, Li DZ, Cannon CH, Chen J, Li QJ. 2011. Phylogeny and evolution of bracts and bracteoles in Tacca (Dioscoreaceae). J Integr Plant Biol 53: 901-911. 
Table S1. List of sampled taxa, vouchers (or source of sequences), localities, and accession numbers included in the phylogenetic analyses. * indicates the taxon included in character mapping analyses. Genbank accession numbers from MK144475-MK153235 are newly generated in this study.

\begin{tabular}{|c|c|c|c|}
\hline \multirow{2}{*}{ Taxon } & \multirow{2}{*}{ Voucher } & \multicolumn{2}{|c|}{ GenBank accession no. } \\
\hline & & ITS & $\operatorname{mat} \mathrm{K}$ \\
\hline Tacca ampliplacenta* & ITS: Zhang et al. (2011); matK: China Plant BOL Group (2011) & JN850566.1 & JF956618.1 \\
\hline Tacca bibracteata* & MALAYSIA. Sarawak: Sri Aman, Lubok Antu, 30 Mar 2018, Wong Sin Yeng \& Peter C. Boyce TA96 (SAR) & MK144508 & MK153225 \\
\hline Tacca borneensis & MALAYSIA: Sarawak, Sarikei, Bayong, Ulu Sarikei, 3 Jun 2017, Wong Sin Yeng \& Peter C. Boyce TA67 (SAR) & MK144485 & MK153202 \\
\hline Tacca borneensis & MALAYSIA: Sarawak, Kapit, Sebabai, 30 Nov 2017, Chua Kek Shen TA77 (SAR) & MK144501 & MK153218 \\
\hline Tacca borneensis & MALAYSIA: Sarawak, Kuching, Bau, Bungo Range, 7 Dec 2017, Chua Kek Shen TA79 (SAR) & MK144502 & MK153219 \\
\hline Tacca borneensis* & MALAYSIA: Sarawak, Kuching, Matang, Kubah National Park, Sep 2017, Chua Kek Shen TA84 (SAR) & MK144491 & MK153209 \\
\hline Tacca borneensis & MALAYSIA: Sarawak, Kuching, Bau, Rajah Brooke Heritage, Sep 2017, Chua Kek Shen TA86 (SAR) & MK144489 & MK153207 \\
\hline Tacca borneensis & MALAYSIA: Sarawak, Kuching, Padawan, Borneo Highland, Sep 2017, Chua Kek Shen TA89 (SAR) & MK144490 & MK153208 \\
\hline Tacca borneensis & MALAYSIA: Sabah, Sandakan, Sepilok, 6 Feb 2018, Wong Sin Yeng \& Peter C. Boyce TA94 (SAR) & MK144504 & MK153221 \\
\hline Tacca borneensis & MALAYSIA: Sabah, Kota Kinabalu, Inanam, 27 May 2018, Wong Sin Yeng \& Peter C. Boyce TA103 (SAR) & MK144510 & MK153227 \\
\hline Tacca borneensis & MALAYSIA: Sabah, Tawau, Lahad Datu, 7 Jul 2018, Wong Sin Yeng \& Peter C. Boyce TA108 (SAR) & MK144514 & MK153231 \\
\hline Tacca chantrieri & Cairns Botanic Gardens, Steve Jackson TA63 & MK144482 & MK153199 \\
\hline Tacca chantrieri & MALAYSIA: Perak, Ipoh, Bercham, 20 Jun 2017, Lim Teow Yeong TA70 (SAR) & MK144517 & MK153234 \\
\hline Tacca chantrieri & MALAYSIA: Selangor, Kuala Lumpur, Bukit Nanas Forest Reserve, Sep 2017, Chua Kek Shen TA91 (SAR) & MK144495 & MK153213 \\
\hline Tacca chantrieri & THAILAND: Satun, Thaleban, 1 Jun 2018, David Scherberich TA105 & MK144512 & MK153229 \\
\hline Tacca chantrieri* & VIETNAM: Kien Giang, Leong, Rach Gia, 1 Jun 2018, David Scherberich TA106 & MK144513 & MK153230 \\
\hline Tacca chantrieri & ITS: China Plant BOL Group (2011); matK: China Plant BOL Group (2011) & JF978861.1 & JF956623.1 \\
\hline Tacca cristata* & MALAYSIA. Selangor: Gombak, FRIM, 17 Dec 2016, Wong Sin Yeng \& Peter C. Boyce TA55 (SAR) & MK144505 & MK153222 \\
\hline Tacca cristata & MALAYSIA: Selangor, Kuala Lumpur, Bukit Nanas Forest Reserve, Jan 2018, Chua Kek Shen TA109 (SAR) & MK144506 & MK153223 \\
\hline Tacca cristata & ITS: Zhang et al. (2011); matK: Wilkin et al. (2005) & JN850568.1 & AY973838.1 \\
\hline Tacca havilandii & MALAYSIA: Sarawak, Sarikei, Bayong, Ulu Sarikei, 3 Jun 2017, Wong Sin Yeng \& Peter C. Boyce TA68 (SAR) & MK144500 & MK153203 \\
\hline Tacca havilandii & MALAYSIA: Sarawak, Kuching, Matang, Sungai Adis, 1 Jul 2017, Chua Kek Shen TA73 (SAR) & MK144492 & MK153210 \\
\hline Tacca havilandii & MALAYSIA: Sarawak, Kuching, Matang, Kubah National Park, Sep 2017, Chua Kek Shen TA88 (SAR) & MK144493 & MK153211 \\
\hline Tacca havilandii* & MALAYSIA: Sarawak, Kuching, Bau, Kampung Segong, Nov 2017, Chua Kek Shen TA92 (SAR) & MK144518 & MK153235 \\
\hline Tacca havilandii & MALAYSIA: Sabah, Sandakan, Sepilok, 6 Feb 2018, Wong Sin Yeng \& Peter C. Boyce TA93 (SAN) & MK144503 & MK153220 \\
\hline Tacca havilandii & MALAYSIA: Sabah, Tuaran, Tamparuli, 28 May 2018, Wong Sin Yeng \& Peter C. Boyce TA104(SAN) & MK144511 & MK153228 \\
\hline Tacca integrifolia* & INDIA: Arunachal Pradesh, 4 Nov 2016, Pascal Bruggeman TA48 (SAR) & MK144516 & MK153233 \\
\hline Tacca integrifolia & Cairns Botanic Gardens, Steve Jackson TA59 & MK144478 & MK153195 \\
\hline Tacca integrifolia & Cairns Botanic Gardens, Steve Jackson TA62 & MK144481 & MK153198 \\
\hline Tacca integrifolia & ITS: Zhang et al. (2011); matK: China Plant BOL Group (2011) & JN850569.1 & JF956637.1 \\
\hline Tacca leontopetaloides & Cairns Botanic Gardens, Steve Jackson TA57 & MK144476 & MK153193 \\
\hline Tacca leontopetaloides & Cairns Botanic Gardens, Steve Jackson TA58 & MK144477 & MK153194 \\
\hline Tacca leontopetaloides & Cairns Botanic Gardens, Steve Jackson TA60 & MK144479 & MK153196 \\
\hline Tacca leontopetaloides* & MALAYSIA: Sarawak, Kuching, Lundu, Sampadi, Sep 2017, Chua Kek Shen TA81 (SAR) & MK144494 & MK153212 \\
\hline Tacca leontopetaloides & ITS: Zhang et al. (2011); matK: Wilkin et al. (2005) & JN850570.1 & AY973839.1 \\
\hline Tacca maculata & Cairns Botanic Gardens, Steve Jackson TA61 & MK144480 & MK153197 \\
\hline
\end{tabular}


Tacca palmata

Tacca palmata

Tacca palmata

Tacca palmata

Tacca palmata*

Tacca palmata

Tacca palmata

Tacca palmata

Tacca palmatifida*

Tacca plantaginea

Tacca plantaginea

Tacca reducta*

Tacca reducta

Tacca subflabellata*

Tacca sumatrana*

Tacca sp. nov. 1

Tacca sp.

Trichopus sempervirens*
MALAYSIA. Sabah: Kudat, Kota Murudu, 11 Feb 2017, Wong Sin Yeng \& Peter C. Boyce TA56 (SAR)

Cairns Botanic Gardens, Steve Jackson TA64

INDONESIA: Kalimantan Barat, Bengkayang, Pajintan, 2 Sep 2017, Wong Sin Yeng \& Peter C. Boyce TA75 (SAR)

MALAYSIA: Sarawak, Kuching, Lundu, Sampadi, Sep 2017, Chua Kek Shen TA80 (SAR)

MALAYSIA: Sarawak, Kuching, Serian, Taman Rekreasi Ranchan, Sep2017, Chua Kek Shen TA83 (SAR)

MALAYSIA: Sarawak, Kuching, Bau, Rajah Brooke Heritage, Sep 2017, Chua Kek Shen TA87 (SAR)

MALAYSIA: Sarawak, Kuching, Matang, Sungai Adis, Sep 2017, Chua Kek Shen TA90 (SAR)

ITS: Zhang et al. (2011); matK: Wilkin et al. (2005)

ITS: Zhang et al. (2011); matK: Wilkin et al. (2005)

Cairns Botanic Gardens, Steve Jackson TA65

ITS: Zhang et al. (2011); matK: Wilkin et al. (2005)

MALAYSIA: Sarawak, Kuching, Serian, Taman Rekreasi Ranchan, Sep2017, Chua Kek Shen TA82 (SAR)

MALAYSIA: Sarawak, Kuching, Bau, Rajah Brooke Heritage, Sep 2017, Chua Kek Shen TA85 (SAR)

ITS: Zhang et al. (2011); matK: China Plant BOL Group (2011)

INDONESIA: North Sumatera, Toba Samosir, Lok Lok Pan, 31 Jan 2018, Pascal Bruggeman TA95

MALAYSIA: Kelantan, Tanah Merah, Hulu Kusial, Guai Ipoh, 16 Mar 2016, Wong Sin Yeng \& Peter C. Boyce TA46 (SAR)

INDONESIA: Jawa Barat, Sukabumi, Pasawahan, 24 May 2018, Albert Doang TA102

ITS: Zhang et al. (2011); matK: Hertweck et al. (2015)
MK144475

MK144483

MK144486

MK144496

MK144499

MK14448

MK144497

JN850571.1

JN850572.

MK144484

JN850574

MK144498

MK144487

JN850575.

MK144507

MK144515

MK144509

JN850576.
MK153192

MK153200

MK153204

MK153214

MK153217

MK153206

MK153215

AY973840.1

AY973841.1

MK153201

AY973842.1

MK153216

MK153205

JF956654.1

MK153224

MK153232

MK153226

KP083035.1 
Table S2. List of morphological characters used in the analyses

\begin{tabular}{ll}
\hline Characters & Character states \\
\hline Habitat & Coastal $(0)$, secondary lowland forest $(1)$, stream bank (2) \\
Length of peduncle & $\leq 30 \mathrm{~cm}(0), 31-60 \mathrm{~cm}(1),>60 \mathrm{~cm}(2)$ \\
Outer bract outline & Ovate $(0)$, linear triangular $(1)$ \\
Number of inner bracts & Two $(0)$, more than two $(1)$ \\
Inner bracts outline & Spathulate $(0)$, ovate $(1)$, linear $(2)$, filiform $(3)$ \\
Color of bracts & Green $(0)$, other color $(1)$ \\
Number of bracteoles & Absent $(0), 1-10(1), 11-20(2),>20(3)$ \\
Length of bracteoles & $\leq 12 \mathrm{~cm}(0), 12-22 \mathrm{~cm}(1),>22 \mathrm{~cm}(2)$ \\
Number of flowers & $\leq 10(0), 11-20(1),>20(2)$ \\
Perianth persistent till fruiting & No $(0)$, yes $(1)$ \\
Number of ovules & $\leq 40(0), 41-100(1), 101-200(2),>200(3)$ \\
Leaf blade outline & Decompound $(0)$, palmate $(1)$, entire $(2)$ \\
\hline
\end{tabular}


Table S3. List of specimens investigated for morphological characters: taxon, locality, GPS (where available), and voucher

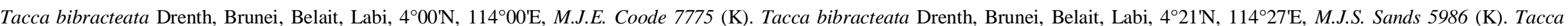
bibracteata Drenth, Brunei, Belait, Melilas, $4^{\circ} 7^{\prime} \mathrm{N}, 114^{\circ} 43^{\prime} \mathrm{E}$, I.M. Said BRUN17311 (K). Tacca bibracteata Drenth, Malaysia, Sarawak, Sri Aman, Lubok Antu, $1^{\circ} 6^{\prime} \mathrm{N}, 111^{\circ} 39^{\prime} \mathrm{E}$, S.Y. Wong \& P.C. Boyce TA-96 (SAR). Tacca bibracteata Drenth, Malaysia, Sarawak, Tubau, P.S. Ashton S. 18369 (K). Tacca borneensis Ridl., Malaysia, Sabah, Kota Kinabalu, Inaman, $5^{\circ} 588^{\prime N}$, $116^{\circ} 12^{\prime} \mathrm{E}$ S.Y. Wong \& P.C. Boyce TA-103 (SAR). Tacca borneensis Ridl., Malaysia, Sabah, Sandakan, Sepilok, S.Y. Wong \& P.C. Boyce TA-94 (SAR). Tacca borneensis Ridl., Malaysia, Sabah, Tawau, Lahad Datu, 50'N, 11744'E, S.Y. Wong \& P.C. Boyce TA-108 (SAR). Tacca borneensis Ridl., Malaysia, Sarawak, Kapit, Sebabai, K.S. Chua TA-77 (SAR). Tacca borneensis Ridl., Malaysia, Sarawak, Kuching, Bau, Bungo Range, $110^{\circ} 6^{\prime} \mathrm{N}, 1^{\circ} 14^{\prime} \mathrm{E}$, K.S. Chua TA-79 (SAR). Tacca borneensis Ridl., Malaysia, Sarawak, Kuching, Bau, Rajah Brooke Heritage, $1^{\circ} 25^{\prime} \mathrm{N}, 110^{\circ} 13^{\prime} \mathrm{E},{ }^{\circ}$ K.S Chua TA-86 (SAR). Tacca borneensis Ridl., Malaysia, Sarawak, Kuching, Matang, Kubah National Park, $1^{\circ} 366^{\prime}$, $110^{\circ} 11^{\prime}$ E, K.S. Chua TA-84 (SAR). Tacca borneensis Ridl., Malaysia, Sarawak, Kuching, Padawan, Borneo Highland, $1^{\circ} 8^{\prime} \mathrm{N}, 110^{\circ} 13^{\prime} \mathrm{E}$, K.S. Chua TA-89 (SAR). Tacca borneensis Ridl., Malaysia, Sarawak, Sarikei, Bayong, Ulu Sarikei, $1^{\circ} 53{ }^{\prime} \mathrm{N}, 111^{\circ} 30^{\prime} \mathrm{E}$, S.Y Wong \& P.C. Boyce TA-67 (SAR). Tacca chantrieri André, Cairns Botanic Gardens, Steve Jackson TA-63. Tacca chantrieri André, Malaysia, Selangor, Kuala Lumpur, Bukit Nanas Forest Reserve, $3^{\circ} 9^{\prime} \mathrm{N}, 101^{\circ} 42^{\prime} \mathrm{E}$, K.S. Chua TA-91 (SAR). Tacca chantrieri André, Malaysia, Perak, Ipoh, Bercham, T.Y. Lim TA-70 (SAR). Tacca chantrieri André, Thailand, Satun, Thaleban, David Scherberich TA-105. Tacca chantrieri André, Vietnam, Kien Giang, Leong, Rach Gia, 10¹'N, 105 ${ }^{\circ} 6^{\prime} \mathrm{E}$, David Scherberich TA-106. Tacca cristata Jack, Malaysia, Negeri Sembilan, Kual Pilah, FMS-2146 (KEP). Tacca cristata Jack, Malaysia, Selangor, Gombak, Forest Research Institute Malaysia, $3^{\circ} 13^{\prime} \mathrm{N}, 1^{\circ} 1^{\circ} 366^{\prime} \mathrm{E}$, S.Y. Wong \& P.C. Boyce TA-55 (SAR). Tacca cristata Jack, Malaysia, Selangor, Kuala Lumpur, Bukit Nanas Forest Reserve, $3^{\circ} 9^{\prime}$ N, $101^{\circ} 42^{\prime} \mathrm{E}$, K.S. Chua TA-109 (SAR). Tacca cristata Jack, Malaysia, Selangor, Ulu Gombak Forest Reserve, FMS-10540 (KEP). Tacca cristata Jack, Malaysia, Selangor, Ulu Langat, C.B. Kloss s.n. (K). Tacca havilandii S.Y. Wong \& K.S. Chua, Malaysia, Sabah, Sandakan, Sepilok, $5^{\circ} 52^{\prime}$ N, $117^{\circ} 56^{\prime} E$, S.Y. Wong \& P.C. Boyce TA-93 (SAN). Tacca havilandii S.Y. Wong \& K. S. Chua, Malaysia, Sabah, Tuaran, Tamparuli, Kampung Minangkob, Murug Turug waterfall, $6^{\circ} 07^{\circ} \mathrm{N}, 116^{\circ} 21^{\prime} \mathrm{E}, S . Y$. Wong \& $P . C$. Boyce TA-104 (SAN). Tacca havilandii S.Y. Wong \& K.S. Chua, Malaysia, Sarawak, Bintulu, Bukit Satiam, 259'N, $112^{\circ} 55^{\prime} \mathrm{E}$, P.C. Boyce \& Jeland ak Kisai TA-10 (SAR). Tacca havilandii S.Y. Wong \& K.S. Chua, Malaysia, Sarawak, Kuching, Bau, Kampung Segong, $1^{\circ} 31$ 'N, $110^{\circ} 8^{\prime}$ E, collector unknown TA-92 (SAR). Tacca havilandii S.Y. Wong \& K.S. Chua, Malaysia, Sarawak, Kuching, Bau, Serikin, P.C. Boyce TA-37 (SAR). Tacca havilandii S.Y. Wong \& K.S. Chua, Malaysia, Sarawak, Kuching, Bau, Sungai Adis, $1^{\circ} 32 '$ N, $110^{\circ} 9{ }^{\prime}$, K.S. Chua TA-73 (SAR). Tacca havilandii S.Y. Wong \& K.S. Chua, Malaysia, Sarawak, Kuching, Bau, Tanjung Durian, P.C. Boyce TA-3 (SAR). Tacca havilandii S.Y. Wong \& K.S. Chua, Malaysia, Sarawak, Kuching, Matang, Kubah National Park, $1^{\circ} 36^{\prime}$ N, 110¹1'E, K. S. Chua TA-88 (SAR). Tacca havilandii S. Y. Wong \& K. S. Chua, Malaysia, Sarawak, Kuching, Matang, Sungai Rayu, Bernard Lee Meng Hock S. 53351 (K). Tacca havilandii S.Y. Wong \& K.S. Chua, Malaysia, Sarawak, Miri, Baram, C. Hose 1357 (G.D. Haviland 949) (SAR). Tacca havilandii S. Y. Wong \& K.S. Chua, Malaysia, Sarawak, Miri, Marudi, Sungai Slat basin, Sungai Palutan, $2^{\circ} 50^{\prime}$ N, 11459'E, S.P. Lim \& L. Banyeng S. 90414 (SAR, KEP). Tacca havilandii S.Y. Wong \& K.S. Chua, Malaysia, Sarawak, Sarikei, Bayong, Ulu Sarikei, Lubok Lemba, $1^{\circ} 53^{\prime}$ N, $111^{\circ} 30^{\prime}$ E, S.Y. Wong \& P.C. Boyce TA-68 (SAR). Tacca havilandii S.Y. Wong \& K.S. Chua, Malaysia, Sarawak, Sarikei, Sungai Lepong, $1^{\circ} 57^{\prime} \mathrm{N}, 111^{\circ} 30$ 'E, P.C. Boyce, Jeland ak Kisai, Jepom ak Tisai, Mael ak Late \& S.Y. Wong TA-33 (SAR). Tacca havilandii S.Y. Wong \& K.S. Chua, Malaysia, Sarawak, Serian, Pichin, Kampung Kakang, Sungai Sisang, P.C. Boyce \& Simon Kutuh ak Paru TA-19 (SAR). Tacca integrifolia Ker Gawl., Bangladesh, Chittagong Hill Tracts, J.L Lister s.n. (K). Tacca integrifolia Ker Gawl., Cairns Botanical Gardens, Steve Jackson TA-59. Tacca integrifolia Ker Gawl., Cairns Botanical Gardens, Steve Jackson TA-62. Tacca integrifolia Ker Gawl., India, Arunachal Pradesh, Pascal Bruggeman TA-48 (SAR). Tacca integrifolia Ker Gawl., India, Assam, s. coll 321 (K). Tacca leontopetaloides (L.) Kuntze, Brunei, Tutong, Danau, $5^{\circ} 45^{\prime} \mathrm{N}, 114^{\circ} 35^{\prime} \mathrm{E}$, L.L. Forman, J.B.J. Blewett 1021 (K). Tacca leontopetaloides (L.) Kuntze, Cairns Botanical Gardens, Steve Jackson TA-57. Tacca leontopetaloides (L.) Kuntze, Cairns Botanical Gardens, Steve Jackson TA-58. Tacca leontopetaloides (L.) Kuntze, Cairns Botanical Gardens, Steve Jackson TA-60. Tacca leontopetaloides (L.) Kuntze, Ethiopia, Illubabor, M. Gashaw, T. Hawaz, M. Zelealem, F. Semon 2 (K). Tacca leontopetaloides (L) Kuntze, Fiji, Beaa Island, M.E. Turbet s.n. (K). Tacca leontopetaloides (L) Kuntze, Fiji, Vanua Levu, O. Degener, E. Ordonez 13996 (K). Tacca leontopetaloides (L.) Kuntze, Malaysia, Kuching, Lundu, Sampadi, K.S. Chua TA-81 (SAR). Tacca leontopetaloides (L.) Kuntze, Malaysia, Malacca, Pulau Besar, H.M. Burkill HMB2764 (K). Tacca palmata Blume, Indonesia, Kalimantan Barat, Bengkayang, Pajintan, $0^{\circ} 51$ 'N, $109^{\circ} 2^{\prime} \mathrm{E}$, S.Y. Wong \& P.C. Boyce TA-75 (SAR). Tacca palmata Blume, Malaysia, Sabah, Kudat, Kota Murudu, $6^{\circ} 16^{\prime} \mathrm{N}, 116^{\circ} 42^{\prime} \mathrm{E}$, S.Y. Wong \& P.C. Boyce TA-56 (SAR). Tacca palmata Blume, Malaysia, Sarawak, Kuching, Bau, Rajah Brooke Heritage, $1^{\circ} 25^{\prime} \mathrm{N}, 110^{\circ} 13^{\prime} \mathrm{E}$, K.S. Chua TA-87 (SAR). Tacca palmata Blume, Malaysia, Sarawak, Kuching, Lundu, Sampadi, $1^{\circ} 41^{\prime}$ N, 110 ${ }^{\circ} 5^{\prime}$, K.S. Chua TA-80 (SAR). Tacca palmata Blume, Malaysia, Sarawak, Kuching, Matang, Sungai Adis, $1^{\circ} 32^{\prime} \mathrm{N}, 110^{\circ} 9^{\prime} \mathrm{E}$, K.S. Chua TA-90 (SAR). Tacca palmata Blume, Malaysia, Sarawak, Kuching, Serian, Taman Rekreasi Ranchan, $1^{\circ} 8$ 'N, $110^{\circ} 344^{\prime} \mathrm{E}$, K.S. Chua TA-83 (SAR). Tacca plantaginea (Hence) Drenth, Cairns Botanical Gardens, Steve Jackson TA-65. Tacca reducta P.C. Boyce \& S. Julia, Malaysia, Sarawak, Kuching, Bau, Rajah Brooke Heritage, $1^{\circ} 25 ' \mathrm{~N}, 110^{\circ} 13^{\prime} \mathrm{E}$, K.S. Chua TA-85 (SAR). Tacca reducta P.C. Boyce \& S. Julia, Malaysia, Sarawak, Kuching, Serian, Taman Rekreasi Ranchan, $1^{\circ} 8$ 'N, $110^{\circ} 34^{\prime}$, K.S. Chua TA-82 (SAR). Tacca sumatrana H. Limpr., Indonesia, North Sumatera, Toba Samosir, Lok Lok Pan, $2^{\circ} 30^{\prime} \mathrm{N}, 99^{\circ} 12^{\prime} \mathrm{E}$, Pascal Bruggeman TA-95 (SAR). 
Table S4. Details of character matrices used for morphological data. Data for T. bibracteata, T. borneensis, T. cristata, T. havilandii, T. integrifolia, T. leontopetaloides, T. reducta and T. sumatrana were obtained in this study, whereas data for the rest of Tacca and Trichopus species were obtained from descriptions of published reports (Drenth 1972, Phengklai 1980, Ling and Ting 1982, Sivarajan et al. 1990, Wilkin et al. 2005, Zhang et al. 2005, Boyce and Julia 2006, Hassan and Uddin 2007, Zhang and Li 2008). Note: "SF" indicates secondary lowland forest, "CS" indicates coastal area, "SB" indicates stream bank, "N/A" indicates not applicable and "_" indicates no data recorded.

\begin{tabular}{|c|c|c|c|c|c|c|c|c|c|c|c|c|c|c|c|c|c|c|}
\hline \multirow{2}{*}{ Species } & \multirow{2}{*}{ Habitat } & \multirow{2}{*}{ Leaf shape } & \multirow{2}{*}{$\begin{array}{l}\text { Peduncle } \\
\text { length }(\mathrm{cm})\end{array}$} & \multirow{2}{*}{$\begin{array}{l}\text { Number } \\
\text { of inner } \\
\text { bracts }\end{array}$} & \multirow{2}{*}{ Outer bract outline } & \multirow{2}{*}{$\begin{array}{c}\text { Inner } \\
\text { bract } \\
\text { outline }\end{array}$} & \multirow{2}{*}{$\begin{array}{c}\text { Color of } \\
\text { bract }\end{array}$} & \multirow{2}{*}{$\begin{array}{c}\text { Perianth } \\
\text { persistent } \\
\text { until } \\
\text { fruiting }\end{array}$} & \multicolumn{2}{|c|}{$\begin{array}{l}\text { Number } \\
\text { bracteoles }\end{array}$} & \multicolumn{4}{|c|}{ of Length of bracteoles } & \multicolumn{3}{|c|}{ Number of flowers } & \multirow[t]{2}{*}{$\begin{array}{l}\text { Number } \\
\text { of } \\
\text { ovules }\end{array}$} \\
\hline & & & & & & & & & Min & Max & Average & Min & Max & Average & Min & Max & Average & \\
\hline T. ampliplacenta & SF & Entire & 40 to 70 & 2 & Ovate & Ovate & Purple & Yes & 6 & 26 & 16 & - & 40.0 & $>22$ & - & 25 & 11.0 to 20.0 & - \\
\hline T. bibracteata & SF & Entire & 15 to 23 & 2 & Ovate & Filiform & Green & Yes & 10 & 16 & 15 & 10.8 & 25.6 & 18.2 & 2 & 10 & 3.5 & 47.3 \\
\hline T. borneensis & SF & Entire & 34 to 47 & 2 & Ovate & Ovate & Purple & Yes & 4 & 9 & 6 & 13.2 & 21.0 & 17.1 & 8 & 22 & 13.6 & 234.0 \\
\hline T. chantrieri & SF & Entire & 63 & 2 & Ovate & Ovate & Purple & Yes & 6 & 26 & 16 & 10.0 & 25.0 & 17.5 & 4 & 25 & 11.0 to 20.0 & 285.0 \\
\hline T. cristata & SF & Entire & 46 & 2 & Ovate & Spathulate & Purple & No & 10 & 25 & 15 & 10.0 & 17.1 & 13.6 & 4 & 19 & 9.9 & 195.8 \\
\hline T. integrifolia & SF & Entire & 44 & 2 & Ovate & Spathulate & Purple & - & 5 & 27 & 16 & 15.5 & 44.2 & 29.9 & - & 30 & 11.0 to 20.0 & 351.0 \\
\hline T. havilandii & SF & Entire & 32 to 58 & 2 & Ovate & Spathulate & Purple/white & Yes & 6 & 12 & 9 & 11.2 & 27.8 & 19.5 & 3 & 12 & 6.6 & 152.6 \\
\hline T. leontopetaloides & CS & Decompound & 91 to 180 & 2 to 9 & Ovate & Spathulate & Green & Yes & 9 & 57 & 22 & 19.8 & 33.2 & 26.5 & 7 & 145 & 46.8 & 70.6 \\
\hline T. palmata & SF & Palmate & 30 to 80 & 2 & Ovate & Spathulate & Green & No & N/A & N/A & N/A & N/A & N/A & N/A & 12 & 23 & 17.3 & 8.0 \\
\hline T. palmatifida & SF & Palmate & 30 to 60 & 2 & Ovate & Spathulate & Green & - & N/A & N/A & N/A & N/A & N/A & N/A & - & 25 & 11.0 to 20.0 & - \\
\hline T. plantaginea & SF & Entire & 7.5 to 25 & 2 & Linear triangular & Linear & Green & No & 6 & 20 & 13 & - & 8.0 & $\leq 12$ & 1 & 13 & $<10.0$ & - \\
\hline T. reducta & SF & Entire & 21 to 30 & 2 & Linear triangular & Linear & Purple & Yes & 10 & 17 & 14 & 10.1 & 20.0 & 15.1 & 2 & 9 & 4.6 & 109.4 \\
\hline T. subflabellata & SF & Entire & 25 to 30 & 2 & Ovate & Ovate & Pink/white & - & - & - & - & - & - & - & 7 & 10 & $<10.0$ & - \\
\hline T. sumatrana & SF & entire & 27 & 2 & Linear triangular & Linear & Purple & - & & 15 & 15 & 7.1 & 13.3 & 10.2 & - & 4 & $<10.0$ & 104.0 \\
\hline Trichopus sempervirens & SB & Entire & Equivocal & Equivocal & I Equivocal & Equivocal & Other color & Yes & - & - & Equivocal & & - & Equivocal & & - & $<10.0$ & $<40.0$ \\
\hline
\end{tabular}


Table S5. Parsimonious steps, likelihood statistics, consistency index and retention index of 12 characters mapped on Maximum Parsimony tree based on combined sequences of ITS and matK of Tacca species and outgroup

\begin{tabular}{lcccc}
\hline Characters & Parsimonious steps & $-\log \mathbf{L}$ & Consistency index & Retention index \\
\hline Number of ovules & 8 & 23.571 & 0.50 & 0.43 \\
Length of bracteoles & 7 & 22.781 & 0.57 & 0.4 \\
Inner bracts outline & 7 & 22.088 & 0.57 & 0.4 \\
Perianth persistent till fruiting & 7 & 16.479 & 0.29 & 0 \\
Number of bracteoles & 6 & 21.704 & 0.83 & 0.5 \\
Length of peduncle & 5 & 17.566 & 0.60 & 0.5 \\
Number of flowers & 5 & 14.591 & 0.40 & 0.4 \\
Outer bract outline & 3 & 11.738 & 0.67 & 0.5 \\
Leaf blade outline & 2 & 9.502 & 1 & 1 \\
Habitat & 2 & 8.037 & 1 & 0 \\
Number of inner bracts & 2 & 8.037 & 1 & 0 \\
Color of bracts & 2 & 6.622 & 0.5 & 0.8 \\
\hline
\end{tabular}

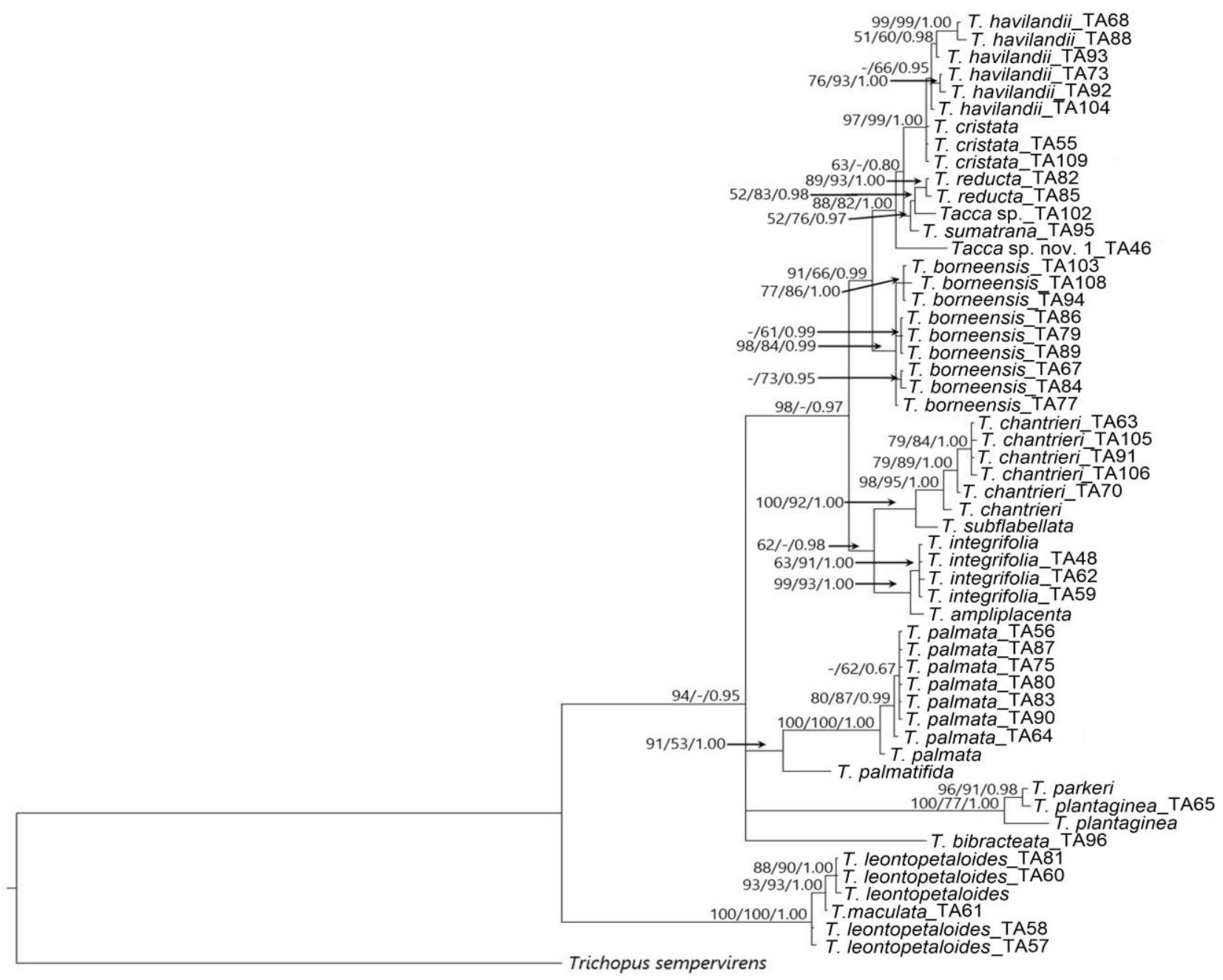

Figure S1. Phylogenetic relationships of Tacca species according to Bayesian Inference of ITS with supporting values above the branch (numbers from left to right indicate Maximum Parsimony bootstrap, Maximum Likelihood bootstrap, and Bayesian Inference posterior probability; "-” indicates bootstrap value less than 50). 


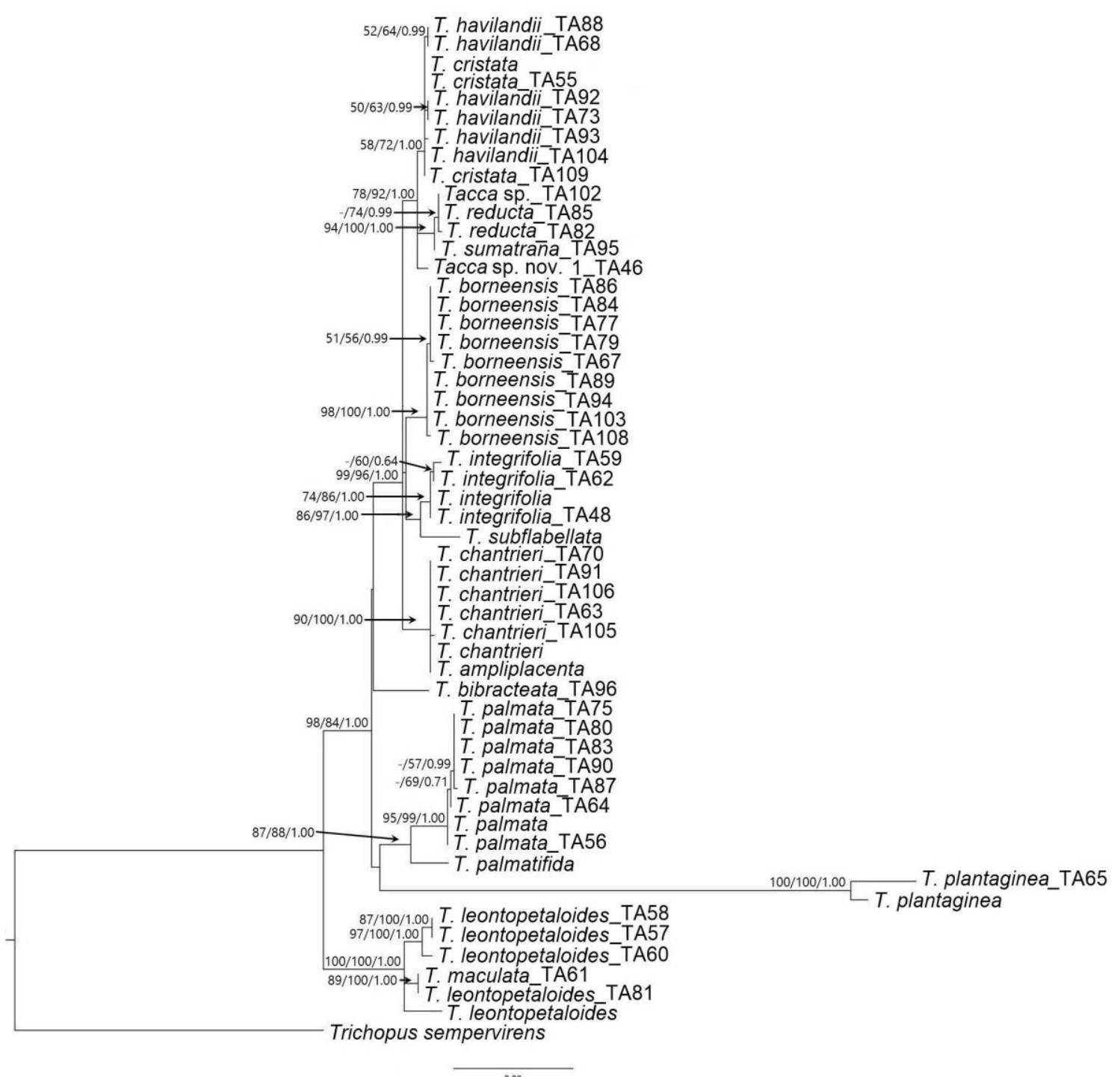

0.02

Figure S2. Phylogenetic relationships of Tacca species according to Maximum Likelihood analysis of matK with supporting values above the branch (numbers from left to right indicate Maximum Parsimony bootstrap, Maximum Likelihood bootstrap, and Bayesian Inference posterior probability; "-” indicates bootstrap value less than 50 